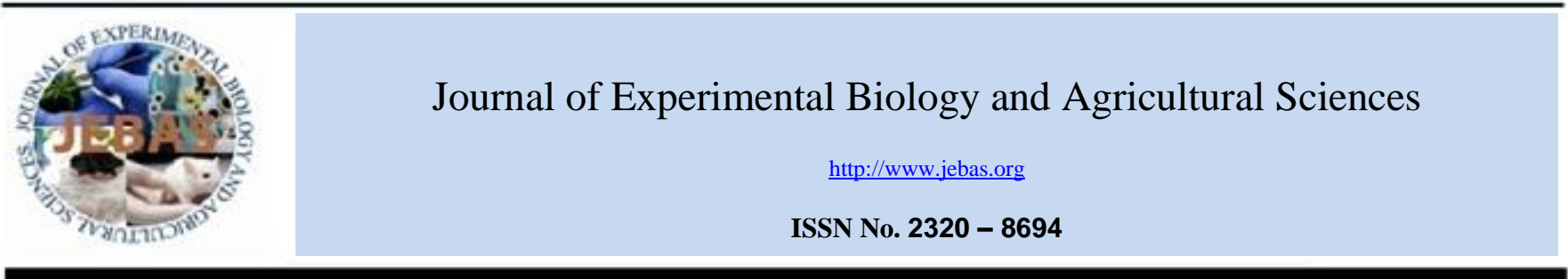

\title{
ZIKA VIRUS / ZIKA FEVER : A COMPREHENSIVE UPDATE
}

Kuldeep Dhama $^{1 *}$, Kumaragurubaran Karthik ${ }^{2}$, Ruchi Tiwari ${ }^{3}$, Rekha Khandia ${ }^{4}$, Ashok Munjal ${ }^{4}$, Sandip Chakraborty ${ }^{5}$, Jay Prakash Yadav ${ }^{6}$, Deepak Kumar ${ }^{7}$, Shyma K Latheef ${ }^{8}$, Mani Saminathan ${ }^{1}$, Yashpal Singh Malik ${ }^{9 *}$, Hafiz M.N. Iqbal ${ }^{10}$, Raj Kumar Singh ${ }^{11}$

${ }^{1}$ Division of Pathology, ICAR-Indian Veterinary Research Institute, Izatnagar- 243122 (UP), India

${ }^{2}$ Central University Laboratory, Tamil Nadu Veterinary and Animal Sciences University, Madhavaram Milk Colony, Chennai, Tamil Nadu - 600051, India

${ }^{3}$ Department of Veterinary Microbiology and Immunology, College of Veterinary Sciences, UP Pandit Deen Dayal Upadhayay Pashu Chikitsa Vigyan

Vishwavidyalay Evum Go-Anusandhan Sansthan (DUVASU), Mathura-281 001 (UP), India

${ }^{4}$ Department of Biochemistry and Genetics, Barkatullah University, Bhopal, Madhya Pradesh- 462026 (MP), India

${ }^{5}$ Department of Veterinary Microbiology, College of Veterinary Sciences and Animal Husbandry, R.K. Nagar, West Tripura 799008, India

${ }^{6}$ Division of Veterinary Public Health, ICAR-Indian Veterinary Research Institute, Izatnagar- 243122 (UP), India

${ }^{7}$ Division of Veterinary Biotechnology, ICAR-Indian Veterinary Research Institute, Izatnagar- 243122 (UP), India

${ }^{8}$ Immunology Section, ICAR-Indian Veterinary Research Institute, Izatnagar- 243122 (UP), India

${ }^{9}$ Division of Biological Standardization, ICAR-Indian Veterinary Research Institute, Izatnagar- 243122 (UP), India

${ }^{10}$ Tecnologico de Monterrey, School of Engineering and Sciences, Campus Monterrey, Ave. Eugenio Garza Sada 2501, Monterrey, N. L., CP 64849, Mexico

${ }^{11}$ ICAR-Indian Veterinary Research Institute, Izatnagar- 243122 (UP), India

Received - October 01, 2017; Revision - October 24, 2017; Accepted - October 02,2018

Available Online - February 20, 2018

DOI: http://dx.doi.org/10.18006/2018.6(1).1.31

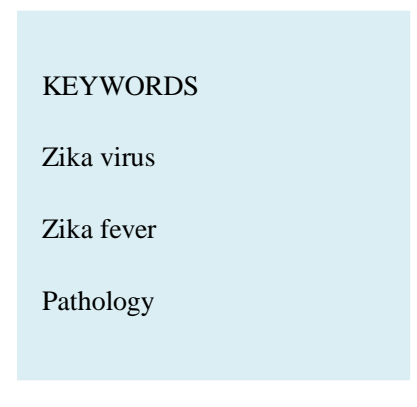

\begin{abstract}
Zika virus (ZIKV) has attracted global attention after its first large-scale outbreak in Pacific, Micronesian island of Yap (Year 2007). The virus spreads rapidly and owes increased virulence than the ZIKV which appeared nearly six decades ago, where it was associated with sporadic cases and mild illness. The World Health Organization declared ZIKA as a 'Public Health Emergency of International Concern" due to severe illness and associated several complications such as neurological disorders, autoimmune disorder, fetal anomalies, impaired central nervous system (CNS) of the fetus, microcephaly
\end{abstract}

* Corresponding author

E-mail: kdhama@ rediffmail.com (Kuldeep Dhama); malikyps@gmail.com (Yashpal Singh Malik)

Peer review under responsibility of Journal of Experimental Biology and Agricultural Sciences.

Production and Hosting by Horizon Publisher India [HPI] (http://www.horizonpublisherindia.in/).

All rights reserved.
All the article published by Journal of Experimental Biology and Agricultural Sciences is licensed under a Creative Commons Attribution-NonCommercial 4.0 International License Based on a work at www.jebas.org.

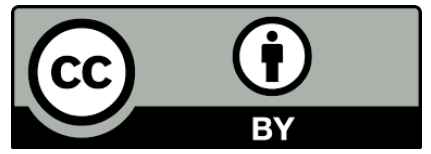




Diagnosis
Vaccines
Drugs
Treatment
Prevention, control

in newborns and Guillain Barre'Syndrome (GBS). Recently, this virus has posed a pandemic threat to global human population. The virus is transmitted primarily by a mosquito (Aedes aegypti), whereas, other routes of viral transmission includes monkey bite, coitus and body fluids such as blood, semen, and saliva which needs further confirmaton. Furthermore, implementation of appropriate mechanical, chemical and biological control methodologies can help to avoid mosquito bites and ultimately limit the viral spread. Another potential approach could be the development of ZIKV resistant mosquito strains such as Wolbachia-harboring mosquitoes which can reduce the incidences of ZIKV by lowering the availability of vectors for virus transmission. In-use ZIKV diagnosis relies on serological, molecular and few other advanced detection methods. Nowadays, worldwide researchers and biomedical and pharmaceutical authorities are paying attention on designing and developing effective vaccines, drugs, medicines, and therapeutics to counter this virus. The reasons behind the shift of virus virulence need to be explored by understanding the genetic and molecular characteristics, host-pathogen interactions and immunobiology of the virus, which would help to design effective antiviral drugs, prophylactics, and vaccines. The present review highlights various aspects of ZIKV and its clinical manifestations, progress, and advances in developing effective diagnostics, vaccines and drugs/therapeutics along with adopting suitable prevention and control strategies to tackle this deadly emerging disease.

\section{Introduction}

Zika virus (ZIKV) is a mosquito-borne virus of the Spondweni serocomplex, genus Flavivirus, family Flaviviridae. Owing to the climate changes like global warming, increasing population dynamics, fast globalization and travel, the human population is facing a rising emergence and outbreaks of mosquito-borne viruses such as Dengue virus, Japanese encephalitis virus, Chikungunya virus, West Nile virus and Zika virus (Chen \& Wilson, 2010; Dhiman et al., 2010; Dhama et al., 2013a; Hubalek et al., 2014; Medlock \& Leach, 2015; Parham et al., 2015; Carneiro \& Travassos, 2016; Gautret \& Simon, 2016; Musso et al., 2017). Soon after the deadly outbreaks of Ebola virus in Western Africa, the most recent emerging virus threatening the global human population is the Zika virus (ZIKV), declared as an emergency situation (Public Health Emergency of International Concern) on February 1, 2016 by the World Health Organization (WHO) for its quick spread, affecting large human population in different countries with pandemic threats (Dhama et al., 2015; Chang et al., 2016; Chen \& Hamer, 2016; ECDC, 2016; Gulland, 2016; Higgs, 2016; Singh et al., 2016; Krauer et al., 2017; Singh et al., 2017). Being remained harmless for six decades (first reported in 1947), the sudden emergence of ZIKV with higher virulence, speedy spread and inducing severe clinical manifestations (especially associated with the cases of microcephaly, unexpected fetal anomalies during gestation period as placental insufficiency, hampered fetal growth, impaired Central Nervous System (CNS) of fetus, fetal death and other neurologic disorders as well as a cluster of Guillain-Barré syndrome) along with little knowledge on suitable prevention and therapeutic measures created massive threats for the human health (Zanluca \& dos Santos, 2016; Cao-Lormeau et al., 2016; Duhaime-Ross, 2016; Gatherer \& Kohl, 2016; Petersen et al., 2016a; Samarasekera \& Triunfol, 2016; Singh et al., 2016; Molko et al., 2017).

Earlier reports on ZIKV were limited to Africa and Asia, while now it has worldwide presence (Hayes, 2009; Heang et al., 2012; Grard et al., 2014; Brown, 2015; Chang et al., 2016; Fauci \& Morens, 2016; Lucey \& Gostin, 2016; Vest, 2017; Zhang et al., 2017). It is noteworthy that since the first report of the disease from the African continent, only 14 cases in humans had been reported before its first large epidemic in the year 2007 on the Island of Yap (Duffy et al., 2009; Marano et al., 2016; Reveiz et al., 2017), followed by the largest outbreak in French Polynesia (October 2013 to April 2014) (Cao-Lormeau et al., 2014; Reveiz et al., 2017). After that in 2015, ZIKV expanded its horizons and also emerged in Vanuatu, Fiji, Solomon and Samoa (ECDC, 2016; Musso et al., 2017). The sequences of ZIKV from Brazil and Suriname upon phylogenetic analysis have revealed their Asian origin. Pacific Islands have been found to be the region from where the virus has entered into the Latin America during some sports events during the year 2014 (Waggoner \& Pinsky, 2016). Since 2015, 76 countries and territories around the world have reported ZIKV transmission, predominantly the South Americas, where Brazil was the most affected country with more than 1.4 million affected cases of Zika alone (Jamil et al., 2016; WHO, 2016; Krauer et al., 2017). With the noticed severity of the recent 
ZIKV outbreak, several countries geared up for epidemiological investigations to know out further disease spread and the serious health concerns (Van Kerkhove et al., 2016; Reveiz et al., 2017).

Notably, in Asia the incidence of ZIKV infection is relatively low when viral detection was done by employing reverse transcription-polymerase chain reaction (RT-PCR). Viremia induced by ZIKV infection is relatively low; thereby decreasing the probability of detecting the virus in blood samples in acute cases. This has led the researchers to make the interpretation of the results by taking extra caution (Shan et al., 2016; Duong et al., 2017). In Asia and America, the strain difference (as far as the infectivity is concerned) could have been responsible for the fundamental difference in the epidemiology as well as the burden of ZIKV infection. The Asian lineage of ZIKV is responsible for most of the recent outbreaks in Asia as well as America (Haddow et al., 2012). There is a requirement of using viruses generated de novo from diverse geographical as well as clinical sources to describe the pattern of ZIKV infection in Asia and America (Setoh et al., 2017).

ZIKV infection impacts any nation's economy adversely besides being a toll on human health (Jamil et al., 2016). International agencies including WHO, Pan American Health Organization (PAHO), the Consortium for the Standardization of Influenza Seroepidemiology (CONSISE), Institute Pasteur, the International Severe Acute Respiratory and Emerging Infection Consortium (ISARIC), Fiocruz, and others have taken up collective steps and are coordinating to synchronize the ongoing research on this virus and complications associated with it (Reveiz et al., 2017).

The emergence of this virus with increased virulence and potential of rapid spread posed pandemic threats to global human population (Chitti et al., 2016; Petersen et al., 2016a). Of note, till 2015 nearly 100 research articles were available in Pubmed and Pubmed Central, while now in January 2018, there are more than 3500 research articles on different aspects of the virus and the disease it causes, which altogether reflects the high concerns and wide attention this pathogen has gained in just past 20 months.

Researchers in many countries are trying hard to counter ZIKV and the Zika fever by carrying out detailed virological, pathological and molecular studies, developing rapid diagnostics, finding out potential drugs, prophylactics, vaccines as well as adopting appropriate prevention and control measures (Keasey et al., 2017; Munjal et al., 2017a; Rather et al., 2017; Shankar et al., 2017; Sharma \& Lal, 2017; Singh et al., 2018a). Rapid diagnostics are now existing for detecting ZIKV infection, many drug and vaccine candidates have also been identified, but still any effective / approved treatment or vaccine is practically lacking against this virus (Dyer, 2016a; Fernandez \& Diamond, 2017;
Munjal et al., 2017a; Munjal et al., 2017b; Passi et al., 2017; Singh et al., 2018b). Appropriate prevention and control strategies include limiting the spread/bite of the vector mosquitoes by checking their population expansion, safe precautions during sexual intercourse and blood transfusions, avoiding travel to Zika endemic countries and surveillance and monitoring are the only feasible options to keep ZIKV infection under limits (Rather et al., 2017; von Seidlein et al., 2017). Here, we present a compilation on the Zika virus/ Zika fever, covering different aspects of the virus and the disease it causes, and describes the ongoing progress and advances being made in the field of designing and developing diagnostics, vaccines, drugs along with prevention and control measures to be adapted to combat this viral pathogen of high public health concerns.

\section{Etiology, Epidemiology and Transmission / Spread}

Zika virus belongs to the genus Flavivirus, family Flaviviridae (Gold \& Josephson, 2016; Paz-Bailey et al., 2017; Uncini et al., 2017). It is a ss-RNA virus of $11 \mathrm{~kb}$ genome size with single open reading frame (ORF) encoding a polyprotein with 03 structural proteins (capsid, pre-membrane, envelope) and 07 non-structural (NS) proteins (NS1, NS2a, NS2b, NS3, NS4a, NS4b, NS5) (Musso \& Gubler, 2016; Kumar et al., 2017). Among these NS5 has multiple roles and protein E plays a pivotal role in binding and fusion of virus as an important basic step for the establishment of ZIKV infection (Dasti, 2016). Various antigenic epitopes are present in the third domain of the E protein and thus essentially targeted as far as the serological tests are concerned. It is also an important target for vaccine development. It is assumed that the global spread of the ZIKV is due to loss of the E protein glycosylation site: N154. This helps the virus to adapt to a broader range of vector mosquitoes (Faye et al., 2014; Chan et al., 2016). From Zika forests of Uganda, the first ZIKV isolation was done in 1947 from rhesus monkey. ZIKV strain 766 particle size ranged between 30 and $45 \mathrm{~nm}$ (Dick, 1952). Recently, the viral structure has been elucidated using cryo-electron microscopy which could assist in designing of antiviral drugs and vaccines (Sirohi et al., 2016).

Consequent to early 2015 Zika disease outbreak in Brazil, the Zika fever spread rapidly across South and Central America, North America, Latin America, Mexico, Colombia, French Polynesia, Cook Islands, Haiti, Panama, Trinidad and Tobago, Samoa, and American Samoa (Campos et al., 2015; Zanluca \& dos Santos, 2016; Rodriguez-Morales, 2015; Nereida, 2015; Summers et al., 2015; Chang et al., 2016; Chen \& Hamer, 2016; ECDC, 2016; Hennessey et al., 2016; Higgs, 2016; Pastula et al., 2016; Petersen et al., 2016b). As per the updates of the Pan American Health Organization (PAHO) vector-borne ZIKV infections have been confirmed in 48 countries and sexual 
transmission in 5 countries regionally. Imported cases have been recorded in people visiting areas where the epidemic infection is prevalent and subsequently returning to Europe, Asia-Pacific and the Americas (Pan American Health Organization/ World Health Organization, 2016; Goorhuis et al., 2016). ZIKV autochthonous (locally transmitted) cases have been reported from many countries or territories (Zanluca \& dos Santos, 2016; Calvet et al. 2016a). The year 2016 also marked the report of first ZIKV infection in Taiwan and PCR followed by further analysis showed that it was Asian lineage virus having close proximity with Cambodian virus (Huang et al., 2016).

The ZIKV transmission mainly takes place via mosquito (Aedes sp.-Aedes aegypti and A. albopictus) in an anthroponotic manner (human-to-vector-to-human), perinatal transmission, sexual intercourse, and blood transfusion (Besnard et al., 2014; Musso et al., 2014, Musso et al., 2015; Franchini \& Velati, 2015; Carneiro \& Travassos, 2016; Marcondes \& Ximenes, 2016; Shoaib et al., 2016). Aedes aegypti was originated from A. aegyptiformosus, a zoophilic tree hole mosquito from African countries while Aedes albopictus is a zoophilic forest mosquito, belongs mainly to Asian countries. A. aegypti mosquito is a most important vector in spreading of ZIKV (Kaddumukasa et al., 2014; Carneiro \& Travassos, 2016). Apart from Aedes mosquito vector other vectors like Culex spp. have also been reported. Studies suggested that around ten species of genus Aedes, Culex perfuscus, Anopheles coustani and Mansonia uniformis have also been reported as a vector for ZIKV (Ayres, 2016). Culex quinquefasciatus was also suspected to play a role in ZIKV transmission as ZIKV RNA was detected from these mosquitoes from North Eastern Brazil and later from China. Thus there may an array of vectors involved in ZIKV transmission which has to be elucidated swiftly to prevent further transmission (van den Hurk et al., 2017). ZIKV transmission from infected pregnant woman occurs through transplacental route and thus affects the brain of the fetus (Roa, 2016; Torjesen, 2016). The mosquito A. aegypti and A. albopictus mainly transmit ZIKV in urban areas while in niche ecotypes $A$. hensili and A. polynesiensis are found to be the vectors. Even though the dominance of the vector A. albopictus is mainly in Asia but the vector has got potential to spread ZIKV infection globally because of its invasive nature and broader distribution geographically (Grard et al., 2014; Ledermann et al., 2014; Weaver et al., 2016). In the tropical and subtropical climate, the rainy season is conducive for the Aedes mosquitoes allowing them to breed and most of the people suffer from mosquito bite during the day (from dawn to dusk) (Ibrahim, 2016). Brain lesions in the non-human primate fetus have developed due to subcutaneous inoculation of ZIKV. Susceptibility in neonatal pigs is also on the higher side (Waldorf et al., 2016; Darbellay et al., 2017). ZIKV transmission from mother to fetus is high in rhesus macaques when the Asian lineage of the virus is inoculated subcutaneously.
Such study is also indicative of the possibilities of mother-fetus transmission in case of human. Studies suggested the transfer of ZIKV from a pregnant mother to fetus and from lactating mother to newborn as well (Jamil et al., 2016). Following inoculation through rectum or vagina in macaques (adult) the rate of infection was found high (Haddow et al., 2017; Nguyen et al., 2017). Some of the cases of asymptomatic ZIKV infections have been found to spread through transfusion of blood during acute viremia. The role of saliva to spread the viral infection is still under study (Oster et al., 2016; Petersen et al., 2016a). Reports are suggestive of ZIKV transmission through infected monkey bite also (Leung et al., 2015).

The isolation of ZIKV from semen is an indication of transmission through coitus (Musso et al., 2015). The first confirmatory case of sexually transmitted ZIKVinfection is from France in 2016 in a woman where her husband acquired the infection during his recent visit to Brazil (Elgot et al., 2016). Recently, a study was conducted to know the site of ZIKV replication in the genital organs which aid in the sexual transmission of the virus. Stromal mesenchymal stem cells and epithelial cells of the human prostate were studied with 3 different ZIKV isolates, and the result showed that ZIKV infection is higher in stromal cells than epithelial cells of the prostate. Thus, findings confirmed that replication of ZIKV can occur in prostate and can spread further through semen (Spencer et al., 2017). RTin situ PCR of the sperm showed that ZIKV was confined to the midpiece of the spermatozoa and hence it was speculated that receptors for ZIKV might be present in the midpiece of the sperm (Bagasra et al., 2017). Present knowledge on ZIKV shows that transmission can occur from male to a female partner, and male can shed ZIKV through semen, but there is no evidence regarding the shedding of virus from the female genital tract. Further research may pave way to find the exact mechanism of transmission and the receptors responsible for ZIKV infection (Epelboin et al., 2017).

\section{Zika Fever - Clinical picture, Pathology and Pathogenesis}

Infection with ZIKV were earlier reported to be asymptomatic in 50 to $80 \%$ cases, and the symptoms of illness being mild and selflimiting, a febrile disease of 3-7 days with no mortality and lesser hospitalizations (Duffy et al., 2009; CDC, 2016; Reveiz et al., 2017). The symptoms are more or less similar to dengue infection expressing fever, anxiety, joint pain, body ache, indicating no special reason to consider Zika virus as the primary cause of illness unless until any neurological or auto-immune disorder develop (Jamil et al., 2016). However, the most recent outbreaks of ZIKV revealed microcephaly in newborn babies (abnormal small heads and brains), and congenital neurological malformations and disabilities in babies, while in adults it mainly 
presented Guillain-Barré syndrome (GBS); apart from these visual impairment cases have also been recorded (de Araújo et al., 2016; Brasil et al., 2016; Cauchemez et al., 2016; Cao-Lormeau et al., 2016; Dos Santos et al., 2016; Cuevas et al., 2016; Martines et al., 2016a; Mlakar et al., 2016; Schuler-Faccini et al., 2016; Shuaib et al., 2016; Rodriguez- Morales, 2016; Reveiz et al., 2017; Ventura et al., 2017). It is reported that ZIKV may not cause congenital brain abnormalities or GBS by itself and some unknown cofactors might be associated along with this virus to cause such serious complications (Reveiz et al., 2017). GBS, an immune-mediated ascending flaccid paralysis, is implicated within a month of ZIKV infection (Willison et al., 2016; Krauer et al., 2017). In patients suffering from GBS, respiratory muscles become gradually weak which led to difficulty in breathing and lead to death or lifetime impaired functions of affected muscles (Jamil et al., 2016). Recently, transient myocarditis has also been found associated with ZIKV infection, and researchers advise electrocardiogram and troponin tests if cardiac signs are suspected of ZIKV infection (Aletti et al., 2017). It is also speculated that hearing loss may also be associated with ZIKV. A study among 104 infants supposed to be infected with ZIKV in Brazil showed 9\% cases affected by hearing loss. Further detailed studies are warranted to unearth the relationship between ZIKV and hearing loss (Mittal et al., 2017). The possibility of vertical transmission of ZIKV is documented in the literature. Calvet et al. (2016b) reported the presence of the ZIKV genome in the amniotic fluid along with the presence of anti-ZIKV IgM antibodies. This implies the ability of the virus to reach the fetal environment thereby suggestive of the possibility of vertical transmission. The presence of ZIKV in the brain tissues of the fetus is also suggestive of vertical transmission (Mlakar et al., 2016). But as IgM cannot cross the placenta, its presence in the fetus is an indication of vertical transmission of ZIKV to cause fetal infection.

The GBS is reported to have an incidence of 0.24 per 1000 cases of ZIKV infections (Cao-Lormeau et al., 2016; Uncini et al., 2017). A recent analysis of Zika-associated GBS from seven countries (Brazil, the Dominican Republic, Colombia, Honduras, El Salvador, Venezuela and Suriname) documented the rapid surge of GBS (2.0-9.8 times higher) as compared to the pre-Zika era (Parra et al., 2016; Dos Santos et al., 2016; Uncini et al., 2017). This remarkable upsurge in GBS cases could inundate hospital and intensive care resources with well-equipped healthcare services (Uncini et al., 2017). It is noteworthy that there is involvement of the Asian/ Pacific lineage of the virus in case of microcephaly cases in Latin America. The rate of restoring the walking capacity in patients with GBS at the post-infection stage is found to be 56\% (Cao-Lormeau et al., 2016; Teruya \& Versalovic, 2017). The other sequel of the disease is the visual impairment in congenital cases which is mainly due to chorioretinal atrophy, mottling of retinal pigment, retinal vasculature and optic nerve abnormalities (Benzekri et al., 2017; Ventura et al., 2017). The congenital Zika syndrome is also associated with arthrogryposis, brain parenchymal atrophy, intracranial calcification, ventriculomegaly, hypoplasia of corpus callosum, brain stem and cerebellum (Mehrjardi et al., 2017; Sousa et al., 2017). The recent ZIKV epidemic in Latin America has also been implicated with observations of severe fetal abnormalities such as spontaneous abortion, stillbirth, microcephaly, hydranencephaly, and placental insufficiency, which might lead to limiting the intrauterine growth of fetuses (Ferguson et al., 2016; Musso \& Gubler, 2016; Kumar et al., 2017). The brain development of the fetus is inhibited by ZIKV which is evident from the neural stem cell death in case of this viral infection. Studies have been conducted in mice time-to-time wherein intraperitoneal injection of the infected materials has resulted in the development of neuropathological lesions involving the brain. There is very less fatality as far as the acute infection is concerned, but certainly, it has been reported in Colombian children suffering from sickle cell disease. There has been no any report of haemorrhagic symptoms in patients infected with ZIKV (Koenig et al., 2016; Tian et al., 2016).

There are still ongoing researches for understanding the mechanism of development of microcephaly along with other neurological disorders in case of ZIKV infection (Araujo et al., 2016; Faizan et al., 2016). There may be involvement of the neural progenitor cells, and most importantly direct suppressive effects of the NS4A and NS4B proteins of the virus on the process of neurogenesis is evident. Cellular death is the outcome of stem cell infection of brain thereby reducing the genesis of neurons further ultimately resulting in retarded brain growth ( $\mathrm{Li}$ et al., 2016; Nayak et al., 2016). It has been found that the subcutaneous inoculation of ZIKV in guinea pig can result in viral invasion and replication in the brain. It has also been shown previously that in mice viz., A129 and AG129 (that have a defect in interferon responses) the concentration of the virus in the brain, as well as spinal cord, is high. In primates (non-human) the viral RNA has been demonstrated after subcutaneous injection of the infected material. However, there is the scope of further researches to determine and to increase our understanding regarding the exact mechanisms involved in microcephaly mediated by ZIKV (Lazear et al., 2016; Kumar et al., 2017). Ancestral analysis of the ZIKV showed that a single point mutation at 139 position of viral polyprotein from serine to asparagine (S139N) led to the increased infection of both mouse and human neural progenitor cells. This alteration also led to higher cases of microcephaly and mortality in infant mice. This study also revealed that this mutational change occurred before French Polynesia ZIKV outbreak in 2013 and it remained constant throughout the outbreak (Yuan et al., 2017). 
Anomalies of the eye may develop due to tropism/ affinity of the virus towards the developing ocular cells (Li et al., 2016). It is important to note that due to interference with the mitotic function ZIKV can cause microcephaly (Bullerdiek et al., 2016). Immunemediated damage of the fetal brain cells may occur if the virus crosses the placental barrier (Wang et al., 2017a).

The neural progenitor cells can be infected by ZIKV thereby producing viremia in the infected mother. This further leads to transfer of the virus maternally (from blood to the fetus) resulting in teratogenic effect (viz., neurological lesions). There is a decrease in posterior white matter along with white matter gliosis (bilateral) in the fetal brain infected with ZIKV in non-human primates. Apoptotic and mitotic figures may appear (Tang et al., 2016; Waldorf et al., 2016). Atrophy of the brain of the fetus along with coarse calcification in the white matter of frontal lobes and reduction of circumference of the brain $s$ revealed by ultrasonography analysis (Melo et al., 2016). Recently, it was found that ZIKV also leads to testicular atrophy upon infection in mouse thereby suggesting serious complications of non-vector transmission of this virus along with reproductive deficiency in males (Uraki et al., 2017). Prolonged viremia is a feature in pregnant women due to replication of the virus in fetus and placenta (Suy et al., 2016). Thrombocytopenia and hemorrhagic signs have been most recently reported (Boyer Chammard et al., 2017).

The ZIKV enters the host cell by binding to virus-specific (AXL, DC-SIGN, Tyro3, and members of the TIM and TAM families of phosphatidylserine receptors) or general (Sulfated polysaccharides) receptors, and after endocytosis via clathrincoated pits ZIKV replicates in the cell cytoplasm (Hamel et al., 2015; Nowakowski et al., 2016). After entry, Flavivirus (Dengue virus) has been reported to activate RIG-I, MDA-5, and TLR3 genes which recognize various pathogen-associated molecular patterns (PAMPs), that plays a role in innate antiviral immunity (Streblowb et al., 2015; Surasombatpattana et al., 2011). The virus derived PAMPs have been reported to stimulate the expression of transcription factor IRF7, which on binding to interferonstimulated response element and lead to the expression of IFN- $\alpha$ and IFN- $\beta$ and several other antiviral genes like OAS2, ISG15, and MX1 (Honda et al., 2005). ZIKV induces autophagy of the infected cell which serves a dual purpose of both activating viral replication as well as an anti-viral effect (Olagnier et al., 2016). Various pro-inflammatory cytokines (IFN- $\gamma$, IL-18, IL-6, TNF- $\alpha$ ) and chemokines (CCL2, CCL5, CCL7, CXCL1, CXCL10) induced after viral infection are responsible for systemic inflammation caused by ZIKV. High levels of cytokines such as IP-10, IL-6, IL-8, VEGF, MCP-1 and G-CSF demonstrated in the amniotic fluid of ZIKV infected pregnant women can be responsible for brain malformation of the fetus (Ornelas et al.,
2017). Activation of the cytokines and chemokines can lead to damage of the tissues. ZIKV can also activate apoptosis and glial cells (Wang et al., 2017b). A non-apoptotic form of cell death can also be induced by ZIKV which is caspase-independent and associated with the appearance of large cytoplasmic vacuoles derived from the endoplasmic reticulum (Monel et al., 2017). Dengue virus antibodies in humans are highly cross-reactive to ZIKV (Priyamvada et al., 2016). Due to the cross-reactivity of anti-flaviviral antibodies, ZIKV infection is facilitated by antibody-dependent enhancement (ADE) phenomenon (Dejnirattisai et al., 2016). Memory $\mathrm{T}$ cells elicited against Dengue virus can identify later ZIKV infection and prior Dengue infection influence the speed, quality, and magnitude of $\mathrm{T}$ cell response against ZIKV (Grifoni et al., 2017). An overview on Zika virus entry, interferon induction, and autophagy during viral infection is depicted in Figure 1.

NS1 protein of ZIKV plays an important role in escaping from immune reponse through complement antagonism. The secreted hexamer molecule (sNS1) present in extracellular environment interacts with the complement system and leads to progeny virus survival (Conde et al., 2016). ZIKV NS4A and NS4B protein inhibits the activation of Akt-mTOR signaling pathway (Asif et al., 2017), which is an important step in regulation of development, proliferation, and inhibition of autophagy in neuronal proginator cells (Franke, 2008). Also, NS5 protein of ZIKV further inhibit interferon pathway through degrading STAT2 (Laurent-Rolle et al., 2014) in a UBR4 independent method (Morrison et al., 2013).

\section{Advances in Diagnosis, Monitoring and Surveillance}

Since there is no pathognomonic clinical sign observed in ZIKV infection, the diagnosis of ZIKV can be made by isolation and identification of the virus, serological diagnosis by ELISA, genomic detection by RT-PCR and employing other advanced diagnostics (Singh et al., 2016; Singh et al., 2018a). Clinical samples for diagnosis include urine, serum, saliva, amniotic fluid, placenta and cerebrospinal fluid (Paz-Bailey et al., 2017). Histopathology and immunohistochemistry of placenta and umbilical cord can also be carried out to detect the presence of ZIKV (Landry \& George, 2017). Isolation of ZIKV can be attempted from mosquitoes in newborn Swiss albino mice following various routes of inoculation namely intracerebral, subcutaneous and intraperitoneal (Marchette et al., 1969; Way et al., 1976). Cell culture can also be employed for isolation of virus using various cell line like rhesus monkey kidney cells (LLC- 192 MK2), Vero cells, and mosquito origin cells like C6/36 (A. albopictus origin), MOS61 or AP-61 cells (A. psuedoscutellaris origin) (Barzon et al., 2016; Waggoner \& Pinsky, 2016). Tests like serum neutralization tests, complement fixation test, and 


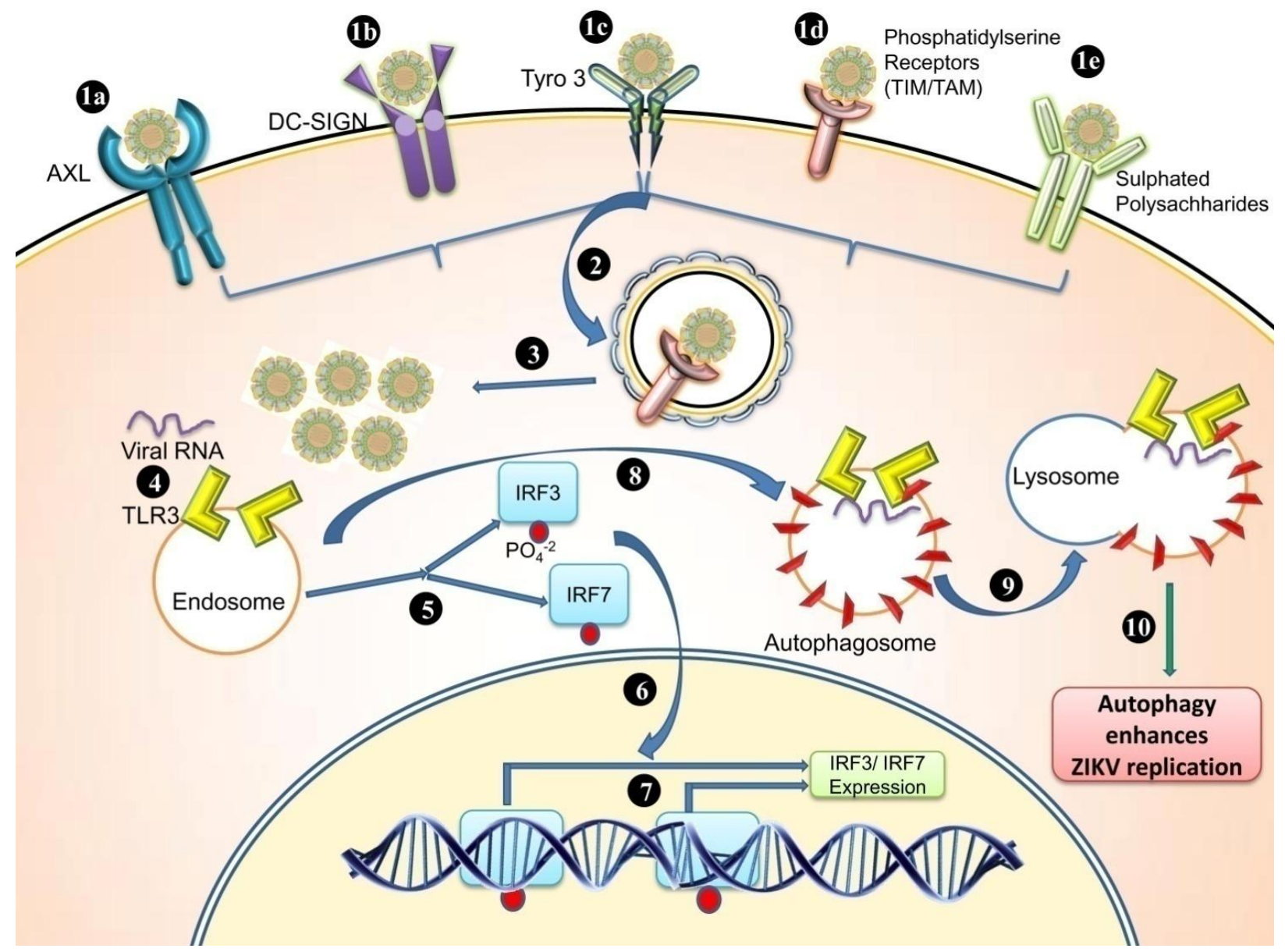

Figure 1 Zika virus (ZIKV) entry, induction of interferons and autophagy: The paradigm during ZIKV infection

(1) a. AXL, b. DC-SIGN, c. Tyro3, d. Phosphatidylserine receptors (TIM / TAM families) or e. Sulfated polysaccharide receptors mediate ZIKV entry,

$\begin{array}{ll}\text { (2) through clathrin-mediated endocytosis, } & \text { (3) ZIKV is released and replicated inside the cytoplasm, }\end{array}$

(4)Viral RNA is recognized by TLR3, $\quad$ (5) Receptor complex activates phosphorylation of IRF3 and IRF7,

(6) Phosphorylated IRF3 and IRF7 moves into the nucleus and binds to antiviral gene elements to express OAS2, ISG15 and MX1,

$\begin{array}{ll}\text { (7) TLR3-ZIKV complex is degraded by } & \text { (8) Formation of autophagosome and }\end{array}$

(9) Fusion of autophagosome to lysosome, and $\quad$ (10) Autophagy enhances ZIKV replication.

Haemagglutination inhibition tests are also used for ZIKV diagnosis (Fagbami, 1979; Monath et al., 1980). It is helpful to collect paired serum samples during the infection to know the status of infection which can be achieved by the use of $\mathrm{IgG}$ and IgM level through ELISA (Pyke et al., 2014). Detection of ZIKV $\mathrm{IgG}$ in the mother during pregnancy can help to find the relationship between ZIKV and congenital abnormalities associated with it (Sumita et al., 2016). Since, IgM does not cross placenta its detection in neonates serum is an important marker for neonatal infection while CSF act as a good indicator of neurologic infection (Cordeiro et al., 2016). Cross-reaction with other flavivirus family members is the major limitation with ELISA, hence plaque reduction neutralization test (PRNT) could be employed for detecting ZIKV to overcome this disadvantage (Granger et al., 2017). Other developments using recombinant non-structural protein 1 (NS1) of ZIKV based ELISA showed a lesser cross-reaction with dengue virus (Steinhagen et al., 2016). Lateral flow assay based on $\mathrm{IgG} / \mathrm{IgM}$ antibodies of ZIKV has been marketed by Chembio Diagnostic Systems (Acharya et al., 2016). Multiplex microsphere immunoassay (MIA) is highly useful in diagnosis ZIKV infection by using asmall volume of thespecimen (Wong et al., 2017). For detecting and quantifying neutralizing antibodies (virus-specific) plaque reduction neutralization test (PRNT) which is having higher specificity than 
ELISA is performed. The false positivity in theserological test can be eliminated by performing this assay along with ELISA (Charrel et al., 2016; Rabe et al., 2016). Several laboratory parameters viz., blood cell count; lactate dehydrogenase in the serum; rise in the concentration of markers (protein) are indicative of ZIKV infection. Assays based on PCR have been approved by the United States Food and Administration (USDA) (Plourde \& Bloch, 2016).

RT-PCR has been used to detect ZIKV genome from saliva, blood, amniotic fluid and amniotic fluid (Faye et al., 2008; Hills et al., 2016; Rather et al., 2017). A recent report states that urine is a better choice for detection of ZIKV by RT-PCR (Bingham et al., 2016). Urine sample offers the ease of sample collection hence identification of ZIKV can be carried out easily with RT-PCR (St George et al., 2017). Altona Diagnostics markets RealStar Zika RT-PCR kit has been reported sensitive and specific in ZIKV detection (L'Huillier et al., 2017). SYBR based real-time RT-PCR has been developed that can detect up to $1 \mathrm{PFU} / \mathrm{mL}$ (Xu et al., 2016a). Real-time RT-PCR assay targeting 5'-untranslated conserved region (5'-UTR) was developed that can detect 5-10 ZIKV RNA copies/reaction, and this assay was very specific for ZIKV detection (Chan et al., 2017a). DNA sequencing NS5, NS3, and envelope gene can help to identify the strains of ZIKV (Fonseca et al., 2014; Grard et al., 2014; Tognarelli et al., 2015). Aptima assay (automated Panther system) for ZIKV detection is based on transcription-mediated amplification (TMA) of highly conserved sequences in NS2 and NS4/5 regions of ZIKV RNA in urine and serum samples. This test is rapid, and yields result in 3.5 hours performed in a single tube (Ren et al., 2017). Recently, multiplex microsphere immunoassay has been developed for ZIKV diagnosis. This test combinedly detects structural envelope proteins of flaviviruses and differentially non-structural proteins (NS1, NS5) thus making it more specific as well (Wong et al., 2017). The diagnosis of ZIKV is also essential to establish its treatment. Recently, a novel real-time multiplex PCR was developed to detect ZIKV and Chikungunya virus. The sensitivity of the developed assay was 0.5 and 1 PFU for Chikungunya virus and ZIKV, respectively (Liu et al., 2017).

One-week post infection detection of IgM antibodies (virusspecific) along with neutralizing antibodies is possible. The virus can be detected by employing another rapid test like RNAbiosensors and RT-loop-mediated isothermal amplification (RTLAMP) too (Tappe et al., 2014; Gourinat et al., 2015). The RTLAMP assay has been reported to be highly specific and sensitive as compared to RT-PCR and real-time PCR (Wang et al., 2016a). Recently, another RT-LAMP was developed to detect ZIKV RNA from urine, and serum samples and the sensitivity was 10 times higher than Real-time RT- PCR, and it could detect 1.2 RNA copies/ $\mu$ of the sample (Calvert et al., 2017). At later stages of viral infection, the real-time RT-PCR (rRT-PCR) technique has been found useful diagnostic tool for detecting viral load in urine as well as serum (Gourinat et al., 2015). RT-LAMP clubbed with lateral flow assay showed detection limit of even single copy number of ZIKV (Lee et al., 2016). Other recent diagnostic techniques like RT-isothermal recombinase polymerase amplification assay (RT-RPA) based on NS2A region of ZIKV was found to be specific and sensitive (Abd El Wahed et al., 2017). Advances in the diagnostics have led to the development of a RT-LAMP assay employing smartphone which is provided with chromaticity algorithm to scan the fluorescent light (Priye et al., 2017). Other techniques like nucleic acid sequence based amplification (NASBA) and RT- strand invasion based amplification (RT-SIBA) were developed for the early diagnosis of ZIKV (Pardee et al., 2016; Eboigbodin et al., 2016). Since, the adverse effects of ZIKV infection are devastating thus it is essential to develop a specific antibody-based nano-enabled electrochemical immunosensing system for rapid diagnosis and immediate care of patients (Kaushik et al., 2017).

Both molecular, as well as serological tests, must be performed in the case of congenital infection. To detect viral antigen immunohistochemistry is recommended. Analysis of the cerebrospinal fluid; placenta or umbilical cord is mandatory to detect a congenital form of ZIKV infection (Martines et al., 2016b; Staples et al., 2016).

The recent advent of the nerve electrophysiology has been attributed to play a critical role in ZIKV associated GBS diagnosis by verifying the occurrence of neuropathy. As pathogenesis of GBS linked with ZIKV has not been explored thoroughly, therefore the interpretation of the results of electrophysiology could establish with regards to what are the components of the peripheral nerve, myelin/axon which are affected primarily (Uncini et al., 2017).

The detection of viral RNA by employing molecular methods is complicated by factors viz., lower load of virus; complexity of the decision making proceure on correct selection of specimen; and specimen collection timing. Moreover, during primary infection, patients mostly remain asymptomatic thereby making the calculation of timing of collection of specimen difficult. But it must be noted that laboratory testing should still be given priority especially in pregnant ladies (George \& Pinsky, 2018).

Animal models always remain critical to understand and to develop counter measures for the epidemic of various animal and human diseases. The guinea pig model act like an animal of choice for diagnosis of ZIKV since it shows similar kind of clinical features and viral kinetics as observed in ZIKV-infected patients, and therefore it may serve to study ZIKV pathogenesis, 
evaluation of vaccines and therapeutics (Kumar et al., 2017). Researchers have documented the mouse model also to study the pathogenesis of ZIKA virus infection (Lazear, 2017).

Surveillance of ZIKV is essential to prevent its transmission further. Geographical information system (GIS) and other surveillance measures can be employed to know the exact status of the disease and its vector density (Dhama et al., 2013b). ZIKA Tracker (zikatracker.net), a mobile application has been developed to report the status of ZIKV aiding in early treatment and control (Kelvin et al., 2016). GeoSentinel Surveillance Network data platform was used during the last outbreak of ZIKV in America and travelers from Canada were screened for acute ZIKV infection (Boggild et al., 2017). During the recent Rio Olympics and Paralympic games athletes, travelers were screened for ZIKV by urine and blood samples using real-time RT- PCR (Shadgan et al., 2016). Advanced diagnostic techniques like biosensors, nanodiagnostics, microarray, LAMP and lateral flow assay should be employed on a regular basis to know the exact status of the disease to aid in prevention and control of ZIKV (Dhama et al., 2014a; Lambe et al., 2016).

\section{Vaccines}

A live attenuated vaccine possessing deletion at the 3 ' untranslated region (ZIKV-3'UTR-LAV) was evaluated for its efficacy in male and female mice. Results showed that challenge with ZIKV after a single dose of the vaccine to male mice protected testes damage while in female mice there was a lower level of ZIKV RNA in the fetus and also in the placenta. Hence, further investigation is required using this vaccine candidate to reach the market (Shan et al., 2017). Plasmid DNA immunization with pre-membrane (prM) and envelope (E) protein has been observed to be protective in mice after ZIKV challenge, mainly owing to the induction of antibodies against E protein (Larocca et al., 2016; Dowd et al., 2016a). It has been proven by a study in mice that when a DNA vaccine that encodes the prM and the E proteins (full length) is injectedintramuscularly, a stronger humoral response is generated compared to a vaccine not encoding the protein prM. Invoice Pharmaceuticals has manufactured another DNA vaccine that provides immunity in rabbit (Dyer, 2016b; Larocca et al., 2016). Inactivated and DNA vaccine for ZIKV has also been verified in rhesus macaques model and the success obtained has upraised the hope for developing suitable ZIKV vaccine for humans (Abbink et al., 2016). DNA vaccines including of GLS5700, VRC5283, and VRC5288, have been studied to provide protection against ZIKV in monkeys (Dyer, 2016a; Hampton, 2016). Phase I study of GLS5700 DNA vaccine among 40 participants divided into 2 groups showed that there were no severe adverse side effects to the vaccine administrated by electroporation. The study also reported the rise in anti ZIKV antibodies thus further clinical studies are needed so that this vaccine can reach the market soon to fight against the important disease (Tebas et al., 2017). Designing of an adenovirus serotype 5-vectored vaccine (Ad5.ZIKV-Efl) has also been reported (Kennedy, 2016; Kim et al., 2016). Computer-aided synthetic peptide vaccine has been designed by targeting ZIKV E, NS3 and NS5 proteins (Mirza et al., 2016). Lipid nanoparticle-encapsulated nucleoside modified mRNA (mRNA-LNP) encoding ZIKV prM and E glycoproteins was found to induce protection from ZIKV challenge in mice (Richner et al., 2017), and a stronger immune response in nonhuman primates, which raised hope for use as a putative vaccine candidate (Pardi et al., 2017). The ZIKV has got structural similarity with Dengue virus (DENV). Partial protection can be provided to mice pups against a lethal challenge of the virus by use of vaccine produced by fusion of recombinant $\mathrm{E}$ (envelop) gene of ZIKV with T4 fibritinfoldon trimerization domain (Efl). Delivery of such vaccine can be done by microneedle array (MNA) which uses carboxymethyl cellulose (Kim et al., 2016; Kostyuchenko et al., 2016).

The ZIKV vaccine can be effectively designed for all the circulating viral strains due to lesser variations reported among the strains (Awasthi, 2016). For Asian-lineage ZIKV, the immune response induced in Indian-origin rhesus macaques against the infecting strain was found to protect from re-infection with homologous viral strain revealing broader immunity (Dudley et al., 2016). Since, only a single ZIKV serotype exists, thus vaccination employing single lineage could stimulate immunity against all the virus lineages (Dowd et al., 2016b). ZIKV primary infection has been reported to be protective against challenge with the heterologous virus by activating T cells, NK cells, B cells and neutralizing antibodies (Osuna et al., 2016). Glycosylation site is essential for effective ZIKV replication in primates; continuous passages of ZIKV in mice brain or cell culture could induct loss of glycosylation site, an important aspect to be considered for developing an effective vaccine against this virus (Aliota et al., 2016a; Dai et al., 2016). The African Strain of ZIKV viz., MR 766 has been used for developing an inactivated vaccine; 100 percent efficacy was observed in AG 129 mice (lacking type I, II interferons) with double vaccine doses after a viral challenge of MR 766 (homotypic) and FSS 13025 (heterotypic) strains (Sumathy et al., 2017).

Analysis of pdmH1N1 influenza virus hemagglutinin subunit 1 (HA1) and ZIKV=E protein indicated that $\mathrm{H} 1$ protein antibodies could neutralize ZIKV. Therefore seasonal influenza vaccine constituted with pdmH1N1 has been suggested to prevent the spread of ZIKV (Veljkovic \& Paessler, 2016). The field of vaccinomics by including individual host genetic differences could pave the novel way to develop a suitable vaccine against ZIKV, as has been exploited by other viruses (Poland et al., 2011; 
Poland et al., 2013). By employing immunoinformatics, linear and conformational B-cell epitopes, and cytotoxic T-lymphocyte (CTL) epitopes could be predicted. Analyzing the immunogenic CTL epitopes with regards to MHC antigen presentation and confirming stability can be done by employing the tool of molecular dynamics. Using 15 conformational CTL epitopes for docking three MHC I proteins and generating virtual state for their interactions, could help in predicting the preliminary set of peptide / antigenic epitopes for generation of peptide-based ZIKV vaccine (Mirza et al., 2016). QTLTPVGRL (MHC class I) and IRCIGVSNRDFV (MHC class II) peptides were reported to be highly conserved antigenic T cell epitopes of Zika virus (Ashfaq \& Ahmed, 2016).

Subunit vaccines are less time consuming to prepare and at the same time safe, but multiple dosing is required (Shan et al., 2016). A subunit vaccine viz., ZIKV E (zE) has been generated, and its production has been made possible by expressing transiently in plant Nicotiana benthamiana. The potency of this new vaccine (plant-based) is either similar or even more than the vaccine platform currently available. The safety level of the plant produced ZIKV E (PzE) is high as the risk of genome getting incorporated, or oncogenesis of nucleic acid-based vaccine (more precisely DNA vaccines) is eliminated. The production cost is also less for such plant-based ZIKV vaccine which encourages its use especially in developing nations where outbreaks of ZIKV infection are most frequent (Tuse et al., 2014; Nandi et al., 2016; Yang et al., 2017).

ZIKV is closely related to other flaviviruses, and the phenomenon of antibody-dependent enhancement (ADE) has been attributed to increasing pathogenicity of ZIKV in the presence of highly crossreactive anti-flavivirus antibodies, which pose multifaceted risk including hindering vaccine development/efficacy (Martins et al., 2016; Barouch et al., 2017). Dengue virus antibodies have been found to promote ZIKV infection in vitro, indicating the role of ADE in viral pathogenesis (Dejnirattisai et al., 2016; Paul et al., 2016).

The genome comparison of ZIKV Asian lineage with other lineages revealed than NS1 of the strain is adapted its codon usage similar to human housekeeping genes (Freire et al., 2015). Poor codon optimization leads to the attenuation of the virus and has vaccinal potential. Knowledge of genetic elements and codon usage may be useful in getting a vaccine strain with optimized immunogenicity and improved safety.

The transmission blocking vaccines (TBVs) could abruptly stop infection (new) in insects that are transmission competent. This is actually a tool that targets the capacity of transmission in the vector and the pathogen can not complete its life cycle within the vector. Potential TBVs can be designed against ZIKV by using proteins of the mosquitoes that are required for infection of the vector (mosquito) by the virus. For reduction of population of vector mosquitoes, implementation of TBVs should be done along with other methods of transmission control viz., insecticides as well as bed nets (Dickson et al., 2014; Londono-Renteria et al., 2016; Anglero-Rodriguez et al., 2017). Of the note, the antigen used in TBVs are intended for vector and does not originate from human source; thereby the antibody titre in vaccinated person is maintained (Coutinho-Abreu \& Ramalho-Ortigao, 2010; Neelakanta \& Sultana, 2015).

The recent scientific advancements made in designing efficient vaccines such as DNA vaccines, plant-based oral vaccines, vectored vaccines, and exploring the novel fields of immunomics, vaccinomics reverse immunology, mathematic modeling, bioinformatics and computer-aided designing of vaccines are suggested to be exploited for developing effective vaccines against Zika fever (Kennedy \& Poland, 2011; Koff et al., 2013; Singh et al., 2015; Kim et al., 2016; Morrison, 2016; Barouch et al., 2017; Bonin et al., 2017; Ding \& Greenberg 2017; Munjal et al., 2017a; Singh et al., 2018b). The utility of toll-like receptor (TLR) agonists, novel adjuvants, and nanotechnology-based delivery would be highly helpful in boosting immune responses and providing sufficient protection to combat ZIKV. Exploring the generation of more knowledge towards knowing the immune mechanisms, viral pathogenesis, molecular and genetic studies, and discovering appropriate and novel vaccine candidates by gaining furher information on ZIKV would be of immense help in formulating effective disease prevention and control strategies (Pierson \& Graham, 2016; Kim et al., 2016; Morrison, 2016; Ding \& Greenberg 2017). Nevertheless, the ZIKV immunity must be thoroughly understood, and various vaccine candidates must be identified properly for complete eradication of this viral disease (Barzon et al., 2016; Kennedy, 2016; Munjal et al., 2017b). An illustration on ZIKV pathology, diagnosis and vaccines are presented in Figure 2.

\section{Treatment: Drugs and Therapeutics}

Till date, no specific anti-viral drug is available to combat ZIKV infection and to protect from its dreadful pandemic threats. Designing of effective/ specific antiviral drugs and therapeutics for safeguarding the health of humans against ZIKV is under high progress (Munjal et al., 2017b; Khandia et al., 2017; Kumar et al., 2017). Some relief to the patient can be provided by timely symptomatic treatment in accordance with the clinical signs. Supportive therapy includes sufficient rest, administration of fluids for preventing dehydration, analgesics for pain relief, antipyretics (acetaminophen or dipyrone) for reducing fever, and checking pruritic rashes by the use of anti-histamines 


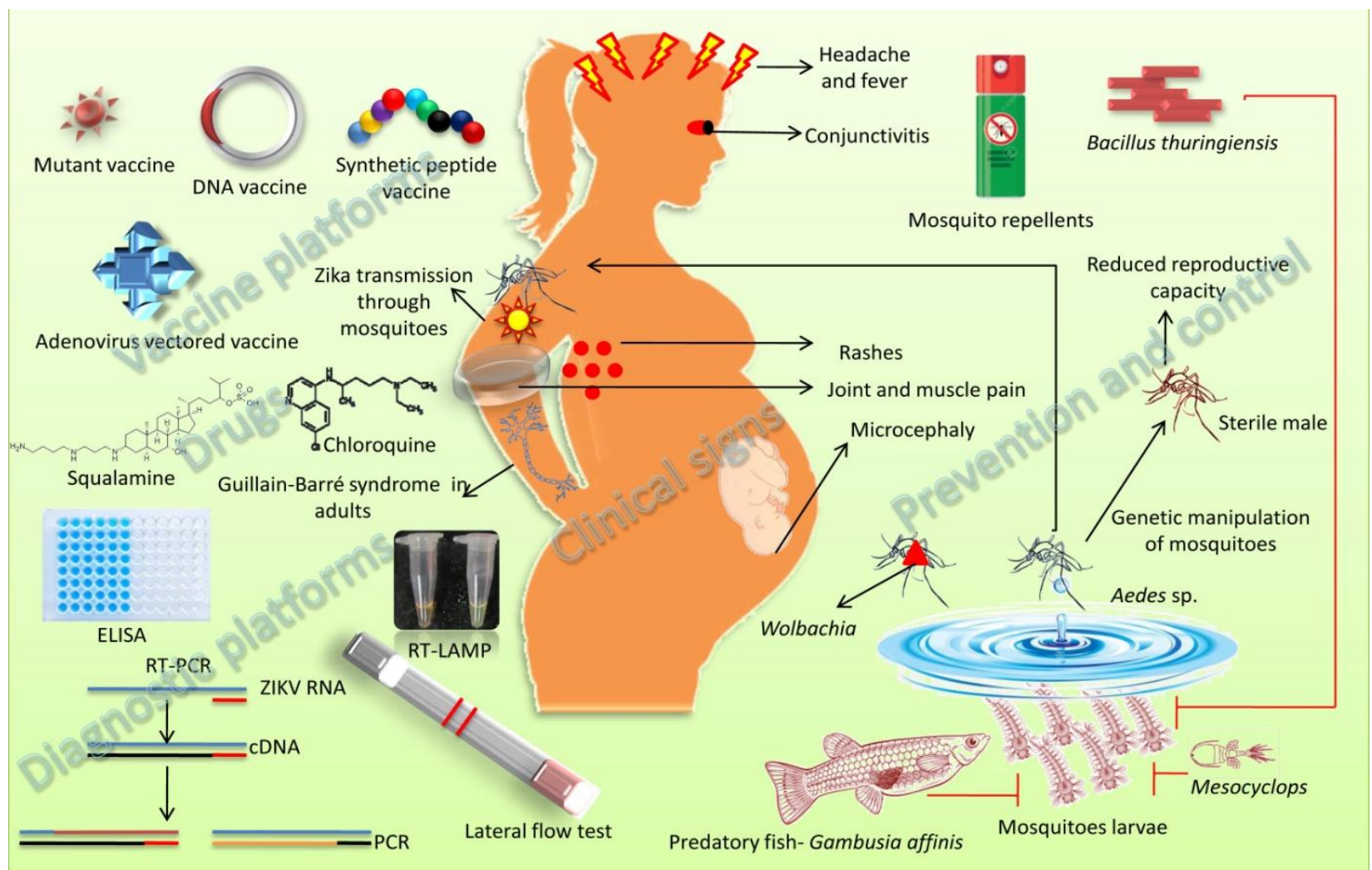

Figure 2 An overview of Zika Virus (ZIKV) pathology, diagnosis and vaccines

(Singh et al., 2016). However, the use of aspirin and non-steroidal anti-inflammatory drugs (NSAIDs) is contra-indicated to avoid any complications such as hemorrhages as noticed in the case of other flaviviruses (DENV and Chikungunya) and also need not be used during pregnancy (Mukherjee \& Era, 2016).

For the fast discovery of anti-ZIKV drugs, several advanced, multidisciplinary and interactive platforms have been initiated globally. For instance, International Business Machines (IBM) has started computer-based world community grid project, Open Zika, where researchers discuss a variety of drug molecules acting against various structures of ZIKV globally (Ekins et al., 2016). Another integrative multi-omics platform, ZikaVR (http://bioinfo.imtech.res.in/manojk/zikavr/), has also been framed for exploring valuable therapeutic regimens like siRNAs, miRNAs, sgRNAs (CRISPR/Cas9 targets). Out of 725 tested compounds, FDA has approved 29 compounds with anti-ZIKV activity and many broad acting anti-viral agents are also offering therapeutic solution against the ZIKV (Adcock et al., 2016; Pascoalino et al., 2016). Among the library of FDA approved drugs, Sorafenib, bortezomib, mycophenolic acid and daptomycin were capable of checking the replication of this virus in human cervical, placental, neural stem and primary human amniotic cells (Barrows et al., 2016; Cheng et al., 2016). ZIKV associated neurodegeneration mimics the hyperactivation of the N-methyl-Daspartate receptor (NMDAR), which leads to accumulation of $\mathrm{Ca}^{2+}$ and subsequent neuronal cell death. Since neurodegeneration is enhanced by N-methyl-D-aspartate (NMDAR) receptormediated neurotoxicity, ZIKV associated neurological complications can be tackled by using NMDAR blockers viz. memantine, dizocilpine, agmatine sulfate or ifenprodil (Costa et al., 2017). Nanchangmycin, a natural product derived from bacteria was found to inhibit the early entry step of this virus in the host cell (Rausch et al., 2017). Memantine, MK-801, agmatine, and ifenprodil are the FDA approved drugs, used in treating Alzheimer's disease and have shown to ameliorate ZIKV mediated neurodegeneration; however it doesn't affect the process of virus replication (Costa et al., 2017). Bromocriptine also has shown some promise in inhibiting ZIKV replication in-vitro possibly through occupying the active site pocket of ZIKV-NS2BNS3 protease (Chan et al., 2017a; Chan et al., 2017b). Antitrypanosomal drug suramin has been reported to inhibit early steps of viral entry and binding, thereby decreasing the number of infective particles (Albulescu et al., 2017; Tan et al., 2017). Post 
attachment step is inhibited by nitazoxanide, an anti-protozoan, and broad spectrum anti-viral pediatric drug (FDA approved). It depletes intracellular $\mathrm{Ca}^{2+}$ levels and inhibits ZIKV replication through an unknown mechanism (Cao et al., 2017). Thus, such compounds in future may be found to provide early intervention in the case of an outbreak (Rausch et al., 2017).Various chemicals / drug formulations are being found to be potent in preclinical studies wherein their clinical translation needs further validations and optimization. Chloroquine is a popular drug which was revealed to lessen the ZIKV infected neural cell counts in mouse neurospheres model by preventing the fusion of virus envelope and endosomal membrane and thus protect mice from fatality (Delvecchio et al., 2016). Another molecule Emricasan, protect neural cells monolayer and organoid cultures by reducing the ZIKV-induced caspase-3 activity, while niclosamide could hamper virus replication and therefore, protect the ZIKV infected cells (Xu et al., 2016b). Azithromycin inhibits ZIKV proliferation in brain cells, consequently can be used for preventing the symptomatic complication of GBS and microcephaly in ZIKV infection (Retallack et al., 2016). Quinacrine, Mefloquine, and GSK369796 like anti-malarial drugs exhibited anti-ZIKV actions by inducing inhibition of autophagy (Balasubramanian et al., 2016).

The USDA approved drug sofosbuvir (SOF) inhibiting the RNA dependent RNA polymerase (RdRp) of the Hepatitis C virus can give both in vitro as well as in vivo protection against ZIKV as evidenced from its protective effect on neural progenitor cells (NPCs) along with the 3D neurospheres from ZIKV induced cellular death. Moreover, SOF treatment re-established antiviral immune responses in the NPCs, and reduced residual virus burden in immune deficient mouse model (Mesci et al., 2018).

Significant overlapping of residues between antigenic sites on the ZIKV polyprotein and other flavivirus proteins has been documented in the epitope-based analysis. Functional antibody epitope sites were found to be shared by E and NS1 proteins, while T cell reactivity was conserved within NS3 and NS5 for ZIKV. This could help in selecting suitable viral regions to act most likely as potential targets of ZIKV-specific antibodies, which could pave the way for developing antibody and $\mathrm{T}$ cellbased therapeutics and prophylaxis (Xu et al., 2016c). Progress in elucidating the structural details of viral proteins will also help in identifying various drug targets to suppress it. NS5 (important protein for ZIKV replication) structure reveals conserved features along with its $\mathrm{N}$-terminal methyltransferase and C-terminal RNA dependent RNA polymerase domains (Stephen et al., 2016; Duan et al., 2017). Sinefungin (pan methyltransferase inhibitor), an adenosine derivative, was found to have selective affinity for this protein hence can serve as a potential inhibitor of ZIKV replication (Coutard et al., 2017; Hercik et al., 2017). In silico approach will certainly help in designing potent drug molecule inhibiting such conserved structures inevitable for viral survival and its pathogenicity (Byler et al., 2016; Ramharack \& Soliman, 2017).

Molecular studies have reported the anti-ZIKV potentials of Berberine (quaternary ammonium salt) and tetrapeptide-Boronic acid compounds as they are capable of inhibiting ZIKV replication and propagation (Sahoo et al., 2016). Obatoclax is a Bcl-2 inhibitor compound and has been recommended for antiZIKV therapy as the mesylate salt of Obatoclax prevented the entry of the virus into the cell by hindering the viral fusion (Varghese et al., 2017). ZINC33683341 and ZINC49605556 are ZIKV envelope protein inhibitory molecules because they bind with viral receptors and adversely affect the virulence (Fernando et al., 2016).

Nucleoside inhibitors of ZIKV such as 2'-C-methylated nucleosides which directly destroy the viral RNA chain (Eyer et al., 2016) and 7-deaza-2'-C-methyladenosine (7DMA) inhibiting the ZIKV replication in Vero cells and mice model, delayed the establishment of disease (Zmurko et al., 2016). 7DMA, being a viral polymerase inhibitor, can restrain ZIKV replication, decrease viremia and impede morbidity and mortality in experimentally infected AG129 (IFN- $\alpha / \beta$ and IFN- $\gamma$ receptor knock-out) mice model (Zmurko et al., 2016). The 2 ' -C-ethynyl and 2' -C-methyl analog of 5' -triphosphates inhibited RNAdependent RNA Polymerase of ZIKV and hence inhibit the viral RNA synthesis by direct termination of the RNA chain translation (Lu et al., 2017). Various patents have already been in progress and granted for antiviral agents among which carba-nucleoside analogs used for flavivirus treatment can also be studied for treatment against ZIKV (Butler et al., 2001). In vitro and in vivo studies conducted in mice documented that Adenosine analog NITD008 also have remedial potentials against ZIKV (Deng et al., 2016a). Another nucleotide analog inhibitor Sofosbuvir (Sovaldi) showed the ZIKV inhibitory activities in human tumor cell lines, human fetal-derived neuronal stem cells, men and nonpregnant women with efficient anti-ZIKA properties but cannot be used in pregnant women (Reznik \& Ashby, 2016; BullardFeibelman et al., 2017). This particular drug inhibits the RNA polymerase of ZIKV directly apart from inducing an accelerated A-to-G mutation in the genome of the virus (Sacramento et al., 2017).

Studies have been made in identifying immune related compounds for combating ZIKV infection. Among interferons, IFN- $\alpha$, IFN- $\beta$, and IFN- $\gamma$ showed inhibitory effect on ZIKV replication, and when added in in-vitro cell culture system used for ZIKV cultivation, IFNs inhibited the ZIKV replication and growth (Contreras \& Arumugaswami, 2016). Anti-TLR molecules can be 
helpful in preventing ZIKV disease outcome by preventing the activation of TLR-3 (Hennessy et al., 2010; Dang et al., 2016). Similarly, Bithionol, caspases inhibitory drug and QL-XII-47's, covalent inhibitors can hamper the Zika viral protein expression to impede the infection (de Wispelaere et al., 2016).

The membrane-associated interferon-inducible transmembrane proteins (IFITMs) are able to inhibit the replication of a wide range of pathogenic viruses including ZIKV. IFITM3 alters the plasma membrane properties and stops fusion pore formation, which is an early stage of virus infection and in result intracellular amount of ZIKV RNA is greatly reduced (Perreira et al., 2013; Savidis et al., 2016). Polyamines are small, positively charged molecules, which are required for life cycle of several RNA viruses. Interferon mediated induction of spermidine/spermine N1-acetyltransferase (SAT1) enzyme, results in conversion of spermidine and spermine into putrescine which leads to restricted ZIKV replication (Pegg, 2008). Cholesterol-25-hydroxylase $(\mathrm{CH} 25 \mathrm{H})$, has been found to be induced upon ZIKV infection and its enzymatic product 25-hydroxycholesterol (25HC), has been revealed to mediate the protection. For instance, synthetically produced and introduced $25 \mathrm{HC}$ blocks ZIKV entry in mice and rhesus macaques, provided protection, prevented microcephaly and reduced viremia ( $\mathrm{Li}$ et al., 2017). Host innate immunity against ZIKV may be improved using M8, a 99-nucleotide long uridine-rich hairpin, which elicits strong interferon response. It is an agonist of the retinoic acid-inducible gene I and inhibits influenza virus and DENV replication in vitro (Chiang et al., 2015) and likely to act against ZIKV too. Another gene RyDEN, is upregulated when interferon treatment is given and in the result, virus yield is reduced (Suzuki et al., 2016). RyDEN forms complex with cellular mRNA-binding proteins and hampers the translation of DENV proteins. Improvement of innate immunity may be used as a universal antiviral system and adapted in case of ZIKV infection also.

Neutralizing antibodies are also effective in controlling ZIKV infection such as, C10, 2A10G6, targeting ZIKV envelope (E) proteins is protective against ZIKV infection in vivo (Dai et al., 2016; Zhang et al., 2016), ZIKV-117 mAb effectively diminishes the ZIKV infection and maternal to fetal viral transfer by neutralizing the several ZIKV lineages at large scale (Sapparapu et al., 2016). Z23 and Z3L1, two MAbs obtained from ZIKV infected patient, were protective in mice which were earlier exposed to ZIKV (Wang et al., 2016b). Convalescent serum possesses ZIKV neutralizing activity due to the presence of high amount of neutralizing serum/antibodies. Studies documented that neutralizing antibodies are capable of crossing the placental and blood-brain barrier of the fetus and cause a reduction in ZIKV infected brain cells and prevent microcephaly in fetal mice when administered intraperitoneallyto pregnant mice and hence safety and efficacy need to be ascertained in pregnant women (Wang et al., 2016c). To counteract ADE in ZIKV infection, a monoclonal antibody with LALA (leucine (L) to alanine (A) substitution at the position 234 and 235 in $\mathrm{Fc}$ region of $\mathrm{IgG}$ antibody) mutation can be used as these cannot bind with Fc $\gamma$ Rs. Hence, such monoclonal antibodies can eliminate ADE of DENV in vitro and in vivo (Williams et al., 2013).

To cure the ZIKV associated ailments, already available drugs may be repurposed after high throughput screening. Khandia et al. (2017) summarized a list of FDA approved drugs, which includes antibiotic, antiemetic, antifungal, antidepressant, anticancer and anti-worm agents and possess activity against ZIKV. The ability of these drugs to pass the blood brain barrier, their chemical properties like hydrophobicity and absorption by gastrointestinal tract are some critical features, which were analysed by Devnarain et al. (2017) using SWISS ADME website. It allows the computation of physicochemical descriptors, pharmacokinetics, druggability and medicinal chemistry friendliness, analysis of compounds. The compounds proposed by Barrows et al. (2016) with potential anti-ZIKV activity were analysed with SWISS ADME; and Fingolimod, Methoxsalen, Palonosetron $\mathrm{HCl}$, Pyrimethamine and Sertraline were found to have ability to permeate the blood brain barrier (Devnarain et al., 2017).

The inhibition of flaviviral genome itself may serve as a therapeutic approach. The flaviviral genome is flanked by 5' and 3' untranslated regions (UTR). The UTRs are responsible for recruitment of RNA polymerase to initiate viral RNA synthesis. Both the 5' and 3' UTR regions are folded to form a stem-loop structure, which is essential for viral replication, and elimination of these stem-loop structure results in abolished replication (Wang et al., 2017a). The 3' stem-loop is structurally conserved in flaviviruses and plays a vital role in the host and viral proteins interaction and is responsible for the regulation of viral multiplication and pathogenicity (Ng et al., 2017). Hence, it is an ideal target to interfere the ZIKV replication through advanced computational approaches so as to design effective siRNAs against 3'UTR (Hashem et al., 2017).

Researches based on herbal compounds are also being undertaken as a potent alternative for the remedial approaches. Among herbal treatments, a study with semi-synthetic compound Xiyanping from Andrographis paniculata was performed for treating Zika fever (Deng et al., 2016b). Andrographolide from Andrographis inhibited NS5 polymerase activity while bisabolol or levomenol obtained from Matricaria recutita and Myoporum crassifolium were found to block NS3 protease (Feranchuk et al., 2016). In vitro studies demonstrated the anti-ZIKV properties of polyphenol and (-)-epigallocatechin gallate (EGCG) present in green tea (Carneiro et al., 2016). Quercitin and Myricetin flavonoids 
allosterically inhibited NS2B-NS3 protease of ZIKV (Roy et al., 2016; Lim et al.., 2016; Lim et al., 2017). The computer-based study revealed the promising potential of balsacone B, kanzonol $\mathrm{V}$, cinnamoylechinaxantholcimiphenol and rosemarinic acid against ZIKV (Byler et al., 2016; Byler \& Setzer, 2016). Cucurmin (a component of turmeric) under in vitro condition was found to inhibit ZIKV binding to its cell surface receptors thereby diminishing its infectivity (Mounce et al., 2017). Plant polyphenolic compound like myricetin has been found efficient in inhibiting NS2B-NS3 protease in a fluorescence resonance energy transfer-based assay (Lim et al., 2017). CN-716, a boronic acid compound forms a complex with NS2B-NS3 protease and inhibits polyprotein processing (Lei et al., 2016). The compound is nontoxic to cultured cells and may be evaluated for its therapeutic efficacy against ZIKV.

A combined use of Chinese (traditional) along with western medicine has been reported in recent past wherein injection of xiyanping has been given intravenously along with administration of ibuprofen (for reduction of fever) and drops of chloramphenicol (for countering conjunctival congestion). Subsequently, the virus has been found to be absent in blood as well as urine (Abushouk et al., 2016). Sophoraflavenone G, isolated from Sophora flavecens, which are used in Chinese medicine were studied for their antiviral activity against flavivirruses. Results revealed that there was inhibition of viral RNA polymerase thus can be used for the treatment of ZIKV infection (Sze et al., 2017).

Few of the upcoming anti-viral therapeutic options may be explored for their possibilities to treat Zika fever and lessen the serious ill effects of ZIKV. These comprise of cytokines, RNA polymerase inhibitors, microRNA, si-RNA, avian egg yolk antibodies (IgY), TLRs, probiotics, herbal remedies, immunomodulators, and nanotechnology based therapeutics / medicines (Blecher et al., 2011; Kawadkar et al., 2011; Dhama et al., 2013c; Dhama et al., 2014b; Dhama et al., 2016; Dhama et al., 2018; Malik et al., 2013; Junquera et al., 2014; Singh et al., 2016; Iqbal et al., 2017; Prasad et al., 2018; Tiwari et al., 2018).

\section{Dissecting Antibody dependent enhancement (ADE) of ZIKV infection}

The ADE is a phenomenon of enhancement of infection due to cross-reactive, but not cross-protective, poorly neutralizing antibodies. The ADE is present in several flaviviruses including DENV, yellow fever virus, Japanese encephalitis virus (Gould \& Buckley, 1989) and West Nile virus (Diamond et al., 2008). The ADE of ZIKV in the presence of DENV antibodies is a matter of debate and particularly becomes important due to the presence of both the viruses in same geographical area. It is not well established that presence of pre-existing DENV antibodies may enhance the risk of ZIKV disease severeity or not. In-vitro results of DENV antibodies mediated enhancement of ZIKV infection (Dejnirattisai et al., 2016) and vice-versa have been documented (Kawiecki et al., 2016; Mahalingam et al., 2017); however, the same phenomemnon is controversial in in vivo experiments. A study conducted on rhesus macaques indicated that in case of secondary DENV1 and DENV4 infection viremia decreased, where during secondary infection with DENV2, viremia increased by 13 folds (Halstead et al., 1973). Using subneutralization concentrations of DENV mAb 1A5, the DENV4 ADE was reported to enhance by 100 folds (Goncalvez et al., 2007). Contradictoryly, another experiment with two cohorts of rhesus macaques, previously exposed to DENV infection and had DENV antibodies did not exhibited severe ZIKV symptoms in comparison to naïve macaques (Pantoja et al., 2017). In fact, preexisting antibodies to DENV1 resulted in higher ZIKV neutralization titer in a cohort study comprising 405 individuals in Brazil and Mexico (Robbiani et al., 2017). Wen et al. (2017) observed that immunity to DENV significantly reduces the ZIKV virus load in different tissues; however the protection was owing to the participation of DENV-specific CD8+ T cells. The contradictory results regarding $\mathrm{ADE}$ in in vivo results can be explained on the basis of fact that there are several mice and primate ZIKV infection models present, however the infection pattern doesnot recapitulate the symptoms occurring in human. The titer is at least 1000 times less in these models than human (Clark et al., 2013) and this might affect the results of ADE also. ZIKV antibody mediated ADE of DENV also has been reported in Rhesus Macaques, where ZIKV antibodies enhaced DENV2 viremia (George et al., 2017). Several other factors like the DENV serotype responsible for antibodies production prior to ZIKV infection, the time interval between DENV and ZIKV infection and parity of DENV serotypes and species under the study are some critical factors which influence the ADE phenomenon amd must be taken into account.

\section{Prevention and control strategies}

\subsection{Strategies for mosquito control}

Due to the lack of any effective vaccine and drugs to fight against ZIKV, presently prevention appears the only way left to keep this virus at bay. Singh et al. (2018b) have recently reviewed the prevention and control stragies to counteract ZIKV. Prevention is mainly aimed at the control of mosquitoes that spread the virus by destroying the breeding space for mosquitoes at any place, avoiding their bites to limit spread of the virus and by developing ZIKV resistant mosquito strains as Wolbachia harboring mosquitoes to reduce the incidences of ZIKV by lowering the availability of vectors for virus transmission (Jamil et al., 2016). 
Methods like chemical, mechanical, biological and sterile male techniques can be employed for control of Aedes sp. (Araujo et al., 2015; Hajra et al., 2016; Singh et al., 2016). Pyrethroids, organophosphorus and organochloride compounds can be used for chemical control of mosquitoes (van den Berg et al., 2012). Use of Wolbachia spp., the intracellular bacterium, reduces mosquito lifespan and releasing mosquitoes infected with Wolbachia has been found effective to control of mosquitoes population, thus reduces transmission of ZIKV by Aedes aegypti by lowering vector competence for the virus (Aliota et al., 2016b; Callaway, 2016). Wolbachia pipientis is a bacteria living in an endosymbiotic manner in mosquito and showed that infectious ZIKV particles are not present in the saliva of Wolbachia-harboring mosquitoes. Employing the mechanism of reproductive parasitism, Wolbachia affects the host mosquito population rapidly and render the cytoplasm incompatible for the growth of other pathogens such as Plasmodium, chikungunya and dengue virus, hence can be used as part of Zika control strategy (Bian et al., 2013; Bourtzis et al., 2014). Such mosquitoes diminish the transmission of Zika. Researchers have confirmed the reduction in levels of ZIKV in saliva and tissues of the abdomen, head, and thoraces of Wolbachia containing mosquito by using TaqManbased qRT-PCR assay (Caragata et al., 2016; Dutra et al., 2016).

The use of predatory tadpoles of frogs to check the larval population of various species of mosquitoes has gained special attention. To study the predatory action on eggs of Aedes aegypti mosquitoes, the tadpoles of various species of frogs namely Bufo; Hoplobatrachus; Ramanella; Polypedates; and Euphlyctis have been taken into consideration. It is interesting to note that in the tadpole guts, the eggs of this particular mosquito species Ae. aegypti have been found indicating the predatory nature for eggs of mosquitoes (Bowatte et al., 2013). The used of silver nanoparticles (synthesized) and leaves of Artemisia vulgaris enhanced the larvivorous characters of tadpole of Hoplobatrachus tigerinus (Murugan et al., 2015a). Scientists are of the opinion that mostly the tadpoles are herbivorous in nature and this finding is inconsistent with respect to earlier findings (Weterings, 2015).

Zingiber cernuum essential oil has been reported to be larvicidal and oviposition deterrent against awide range of mosquito species (Rajeswary et al., 2017). Bacteria of the genus Asaia is a normal inhabitant of the gut of female mosquitoes and reproductive tract of male mosquitoes. Hence, genetic manipulation of Asaia can help to reduce the lifespan of mosquitoes as the bacterium is transmitted vertically and horizontally (Rossi et al., 2015). Bacillus thuringiensisisraelensis was also found effective against larva and adult mosquitoes (Kollars, 2016). Plant extract of Limonia acidissima (Linn.) was found to possess ovicidal activity against Culex quinquefasciatus and A. aegypti (Reegan et al.,
2015). Clusia fluminensis extract (clusianone) showed inhibitory activity against $A$. aegypti (Anholeti et al., 2015).

The predatory effect of crustacean Mesocyclops aspericornis increased when a lower concentration of gold nanoparticles synthesized from Cymbopogon citratus was used (Murugan et al., 2015b). Similarly, the predatory activity of Goldfish has been reported to be increased by the use of silver nanoparticles synthesized from Azadirachta indica seed kernel (Chandramohan et al., 2016). Ichnocarpus frutescens silver nanoparticle possess larvicidal activity against different Aedes sp. mosquitoes (Govindarajan et al., 2016). Essential oil from Syzygium lanceolatum possesses larvicidal activity hence can be used as mosquito repellent (Benelli et al., 2016). Beauveria bassiana and Metarhizium anisopliae fungus can also be used for control of mosquitoes (Tiago et al., 2014). Predatory fishes like Gambusia affinis, Poecilia reticulate, etc., can be used as a larvicidal agent in water bodies (Sarwar, 2015).

The ZIKV transmission cycle can be hindered by genetic manipulation using certain bacteria viz., Wolbachia which will create a cascading effect upon entry into a vector population (cycling pool). The cascade effect is due to the subsequent increase in the population of mosquitoes carrying Wolbachia (Weaver, 2013; Nguyen et al., 2015). Genetic tailoring of mosquitoes can be done for transmitting lethal gene (in offspring) and this is governed genetically by the tetracycline gene. Thus there is requirement of tetracycline in the aquatic environment (usually absent in environmental water) by the offsprings of the mosquitoes that are tailored genetically. Ultimately the larva dies (Specter, 2012; von Seidlein et al., 2017). Sterile male technique by modulating the genes reduces the life cycle of the mosquitoes (Benelli, 2016). The use of mosquito strains that are genetically modified viz., OX513A can reduce the population of A. aegypti locally. This is because there will be the elimination of the female mosquitoes (wild-type) due to mating with male mosquitoes that are genetically modified (Alphey \& Alphey, 2014). The disadvantage of the sterile male technique is the involvement of high cost for engineering the mosquitoes on large scale basis (Vythilingam et al., 2016). On the other hand, the advantage is that there will be enhancement of communication between the policy imakers and practitioners (both from public and health sector) to use mosquitoes (modified genetically) to counteract ZIKV infection (Adalja et al., 2016). RNAi technique is employed to suppress the genes expressed in testes of the male mosquitoes (Whyard et al., 2015). Over a period of time the population of mosquitoes can be reduced by use of sterile males for induction of sterility in females (wild as well as fertile). Identification of 37 genes has been done by use of a suppression subtractive hybridization technique. Expression of such genes mainly takes 
place in the testes of the mosquito (Aedes aegypti). For the purpose of knockdown (mediated by RNAi) for the induction of sterility in males 10 genes (subsets) are chosen. There is introduction of sterility in males by $9 / 10$ knockdowns (in above 50 per cent males) and the fecundity is reduced in rest of the insects (Whyard et al., 2015; Singh et al., 2016). Mating with sterile males alters blood feeding capability and oviposition in female mosquitoes (Alfonso-Parra et al., 2016). Pyriproxyfen as a synthetic hormone analog also prevents $A$. aegypti mosquitoes (von Seidlein et al., 2017).

\subsection{Strategies for Human Interventions}

Vector transmission is not the only way by which ZIKV spreads. There are many non-vector borne routes that have to be kept in mind while designing control strategies against this virus spread. Most importantly the general public needs to be aware of the health complications of ZIKV to follow basic steps of cleanliness to ensure no breeding space for larvae of vector mosquito (Grischott et al., 2016). It is now known that ZIKV is detected in saliva and also from semen hence safe sexual contact (using contraceptives) is advised (Musso et al., 2015; Mansuy et al., 2016; D’Ortenzio et al., 2016; Atkinson et al., 2016). ZIKV has also been detected in breast milk yet there is no report of Zika transmission through breast milk (Dupont-Rouzeyrole et al., 2016). Hence, CDC advises Zika infected mothers to feed their child. Transfusion-transmitted arboviruses remained a challenge for blood transfusion. In this context, the possibility of ZIKV through blood transfusion cannot be ruled out, hence pasteurization of plasma-based products can nullify the virus (Blümel et al., 2016; Kühnel et al., 2016; Farcet \& Kreil, 2017). Along with it, possible preventive measures also include nucleic acid test (NAT) and pathogen inactivation (PI) using amotosalenultraviolet A (UVA) illumination (Musso et al., 2014; Musso et al., 2017). These preventive measures (NAT \& PI) were adopted during the French Polynesian ZIKV outbreak in 2013-2014 (Musso et al., 2014; Musso et al., 2017). In the areas where cocirculation of several arboviruses has been reported, implementation of multiple licensed blood screening tests or designing a cost-effective multiplex assay (including ZIKV, DENV, and CHIKV) for testing of multiplenumbers of pathogens in the single reaction should be emphasizedin the near future (Musso et al., 2017). Inactivation of ZIKV by amotosalen-UVA illumination has recently been demonstrated (Aubry et al., 2016; Santa Maria et al., 2017). By the use of amotosalen combined with UVA light ZIKV was inactivated in fresh-frozen plasma by $6.57 \log _{10} \mathrm{TICD} \mathrm{D}_{50} / \mathrm{mL}$ for infectious particles and $10.25 \log _{10}$ copies/mL for viral RNA (Aubry et al., 2016; Musso et al., 2017).
It is advisable to avoid sexual intercourse during traveling the infected area, or in case one of the partners is virus infected. Individuals must wait for at least 28 days allowing an incubation period of 2 weeks and an additional 2 weeks for the period of viremia to get over if they are planning to conceive after returning from endemic areas. Recently, it was reported that higher percentage of ZIKV infected travelers (99\%) showed symptoms within 2 weeks, of which $50 \%$ showed symptoms within a week of infection. It was also reported that mode of transmission may be sexual or through the local mosquitoes bite and may not be associated with traveling if the symptoms develop after 2 weeks (Krow-Lucal et al., 2017). A surveillance period of at least one month is recommended for such visitors (Maharajan et al., 2016; Rather et al., 2017). The microcephaly associated with ZIKV infection can be minimized in endemic nations by the provision of parental care along with contraceptives (Sharma \& Lal, 2017).

The European Centre for Disease Prevention and Control (ECDC, 2016) and the Food and Drug Administration (FDA, 2016) have issued recommendations to prevent the transmission and spread of ZIKV during a blood transfusion. In areas without having an active circulation of $\mathrm{ZIKV}$, the main recommendation is a postponement of blood donors at risk of ZIKV infection. In areas with active ZIKV circulation, the main recommendations are to supply blood banks with blood products collected in areas without active circulation of ZIKV, or, in the case of blood products are collected locally (especially for at-risk recipients: pregnant women and fetuses given intrauterine transfusion), postponement of blood donors at risk of ZIKV infection, exertion of PI for platelets and plasma, use of NAT and post-donation follow-up should be recommended (Musso et al., 2017). Pregnant women should avoid travel to countries endemic for Zika. Surveillance and monitoring measures at places where people crowd most need to be followed. Enhanced biosecurity principles and necessary guidelines need to be executed globally to prevent as well as check the spread and transmission of ZIKV to different parts of the world (Maharajan et al., 2016; Marano et al., 2016).

Development of preventive vaccines; an improved understanding and knowledge of the immunity to ZIKV for determining the efficacy as well as immunogenicity of the vaccine against the virus and thereby providing protection should be among the top priorities in the research arena. Side by side the molecular basis of neurological outcomes and congenital disorder in relation to infection due to ZIKV should also be studied and communicated rigorously among research groups (Makhluf \& Shresta, 2018; Poland et al., 2018). An illustration summarizing mosquito prevention and control approaches for ZIKV is presented in Figure 3. 


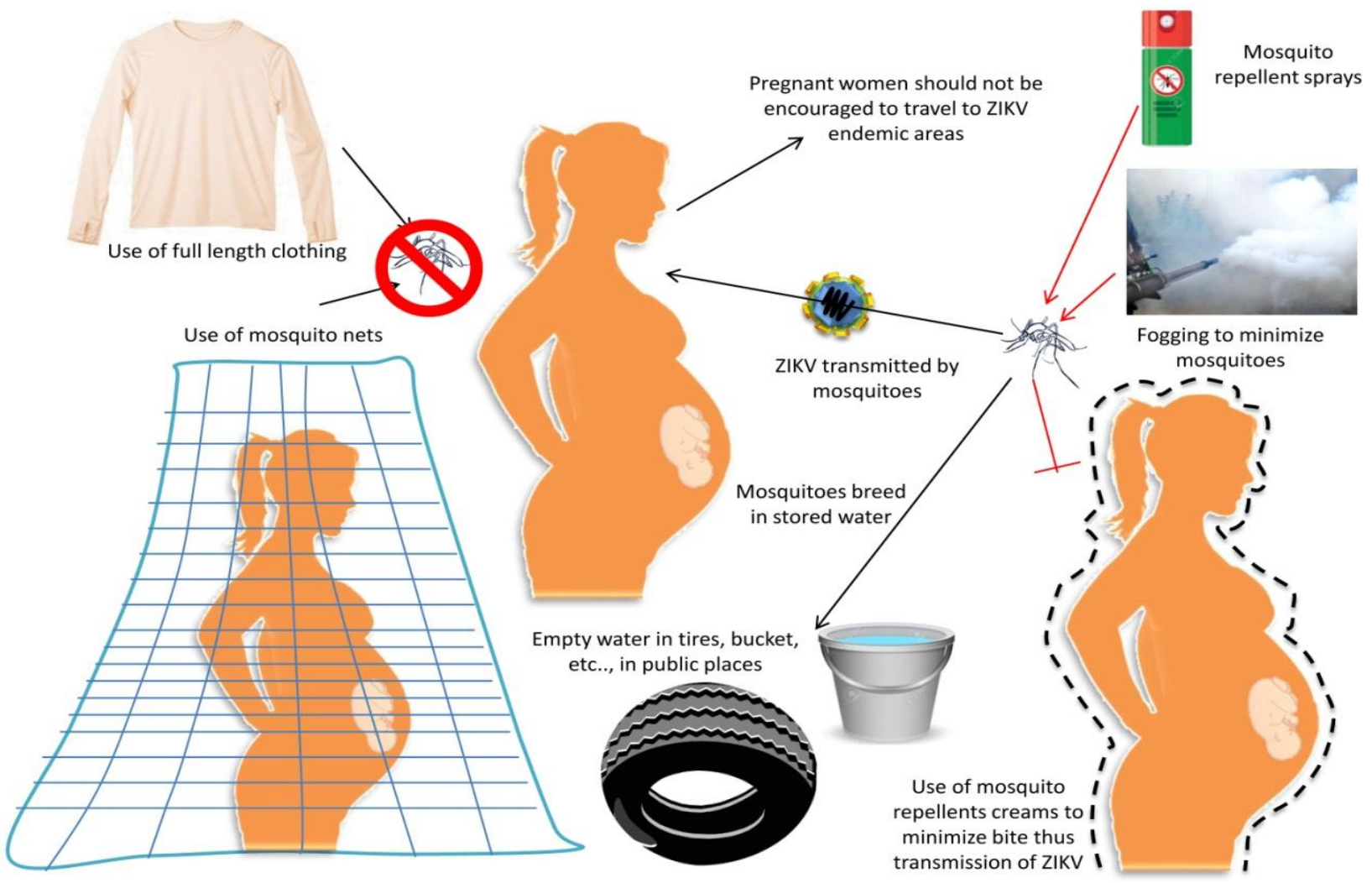

Figure 3: Mosquitoe prevention and control approaches for Zika virus

\section{Conclusion and Future Directions}

ZIKV has acquired a prominent place among several dreaded infectious diseases which are of great concern among the people around the globe. Its major concern is in pregnant women wherein it causes microcephaly, visual impairment and autoimmune disorders namely Guillain Barre'Syndrome. The virus mainly spreads through the bite of mosquito (Aedes spp.), hence prevention and control of mosquitoes become of prime importance to keep transmission of Zika under check. Randomized control trials (RCT) must be carried out for preventing an epidemic. In addition to checking vector transmission, it is also necessary to prevent non-vector transmission of ZIKV as it also has some role to play in maintaining its cycle. For this purpose, public awareness about the disease epidemiology and transmission is essential. Diagnosis of ZIKV can be achieved by the isolation and identification which requires biosafety procedures, serological assays like ELISA which can show cross-reaction with other flaviviruses, nucleic acid detection methods like RT-PCR, real-time RT-PCR, RTLAMP, etc. Samples like urine, amniotic fluid, and other body fluids can be used for diagnosis of ZIKV. Advanced diagnostic techniques like LAMP, lateral flow assay, microarray, nanotechnology can be used for accurate and effective diagnosis of Zika. Accurate phenotyping and serial electrophysiology can provide insight into GBS pathogenesis, especially on the occasions during lack of pathological samples. Presently, several companies are on the verge of designing an effective vaccine against ZIKV. Point-of-care diagnostic kit is the need of the hour to give an early diagnosis for implementing patient care with immediate effect. Efforts must be made for discovering effective drugs to counter ZIKV infection. Several herbal drugs have also been studied to find out an effective control strategy. Further insights into the viral pathogenesis and molecular studies can aid in sketching a better vaccine and treatment options to control ZIKV disease. The research gaps such as the frequency and spectrum of outcomes in the case of ZIKV infection of the fetus must be understood fully; vis-à-vis, there is also need to understand the environmental factors that influence outbreaks. All these will ultimately help to design new products for control of vectors; therapeutics with high efficacy; and effective vaccines for protection of humans. 


\section{Acknowledgement}

All the authors acknowledge and thank their respective Institutes and Universities.

\section{Conflicts of interest}

All authors declare that there exists no potential conflict of interest.

\section{References}

Abbink P, Larocca RA, Rafael A, Bricault CA, Moseley ET, Boyd M, Kirilova M, Li Z, Ng'ang'a D, Nanayakkara O, Nityanandam R, Mercado NB, Borducchi EN, Agarwal A, Brinkman AL, Cabral C, Chandrashekar A, Giglio PB, Jetton D, Jimenez J, Lee BC, Mojta S, Molloy K, Shetty M, Neubauer GH, Stephenson KE, Peron JP, Zanotto PM, Misamore J, Finneyfrock B, Lewis MG, Alter G, Modjarrad K, Jarman RG, Eckels KH, Michael NL, Thomas SJ, Barouch DH (2016) Protective efficacy of multiple vaccine platforms against Zika virus challenge in rhesus monkeys. Science 353:1129-1132.

Abd El Wahed A, Sanabani SS, Faye O, Pessôa R, Patriota JV, Giorgi RR, Patel P, Böhlken-Fascher S, Landt O, Niedrig M, Zanotto PM, Czerny CP, Sall AA, Weidmann M (2017) Rapid Molecular Detection of Zika Virus in Acute-Phase Urine Samples Using the Recombinase Polymerase Amplification Assay. PLoS Current pii: 9. ecurrents.outbreaks.a7f1db2c7d66c3fc0ea0a774305d319e.doi:10.1371/curr ents.outbreaks.a7f1db2c7d66c3fc0ea0a774305d319e.

Abushouk AI, Negida A, Ahmed H (2016) An updated review of Zika virus. Journal of Clinical Virology 84:53-58.

Acharya D, Bastola P, Le L, Paul AM, Fernandez E, Diamond MS, Miao W, Bai F (2016) An ultrasensitive electrogenerated chemiluminescencebased immunoassay for specific detection of Zika virus. Nature (Scientific Reports) 6:32227. doi:10.1038/srep32227

Adalja A, Sell TK, McGinty M, Boddie C (2016) Genetically modified (GM) mosquito use to reduce mosquito-transmitted disease in the US: A community opinion survey. PLoS Current 25: 8. doi: 10.1371/currents.outbreaks.1c39ec05a743d41ee39391ed0f2ed8d3.

Adcock RS, Chu YK, Golden JE, Chung DH (2016) Evaluation of antiZika virus activities of broad-spectrum antivirals and NIH clinical collection compounds using a cell-based, high-throughput screen assay. Antiviral Research 138:47-56. DOI: https://doi.org/10.1016/j.antiviral.2016.11.018.

Albulescu IC, Kovacikova K, Tas A, Snijder EJ, van Hemert MJ (2017). Suramin inhibits Zika virus replication by interfering with virus attachment and release of infectious particles. Antiviral Research 143:230-236.

Aletti M, Lecoules S, Kanczuga V, Soler C, Maquart M, Simon F, LeparcGoffart I (2017) Transient myocarditis associated with acute Zika virus infection. Clinical Infectious Diseases 64: 678-679. DOI: https://doi.org/10.1093/cid/ciw802.

Alfonso-Parra C, Ahmed-Braimah YH, Degner EC, Avila FW, Villarreal SM, Pleiss JA, Wolfner MF, Harrington LC (2016) Mating-induced transcriptome changes in the reproductive tract of female Aedes aegypti. PLoS Neglected Tropical Diseases 10, e0004451. doi:10.1371/journal.pntd.0004451.

Aliota MT, Dudley DM, Newman CM, Mohr EL, Gellerup DD, Breitbach ME, Buechler CR, Rasheed MN, Mohns MS, Weiler AM, Barry GL, Weisgrau KL, Eudailey JA, Rakasz EG, Vosler LJ, Post J, Capuano S 3rd,
Golos TG, Permar SR, Osorio JE, Friedrich TC, O'Connor SL, O'Connor DH (2016a) Heterologous protection against Asian Zika virus challenge in rhesus macaques. PLoS Neglected Tropical Diseases 10: p.e0005168. DOI: https://doi.org/10.1371/journal.pntd.0005168

Aliota MT, Peinado SA, DarioVelez I, Osorio JE (2016b) The wMel strain of Wolbachia Reduces Transmission of Zika virus by Aedes aegypti. Scientific Reports 6: 28792. DOI: 10.1038/srep28792.

Alphey L, Alphey N (2014) Five things to know about genetically modified (GM) insects for vector control. PLoS Pathogens 10:e1003909. doi: 10.1371/journal.ppat.1003909.

Anglero-Rodriguez YI, MacLeod HJ, Kang S, Carlson JS, Jupatanakul N, Dimopoulos G (2017) Aedes aegypti Molecular Responses to Zika Virus: Modulation of Infection by the Toll and Jak/Stat Immune Pathways and Virus Host Factors. Frontiers in Microbiology https://doi.org/10.3389/fmicb.2017.02050.

Anholeti MC, Duprat RC, Figueiredo MR, Kaplan MAC, Santos MG, Gonzalez MS, Ratcliffe NA, Feder D, Paiva SR, Mello CB (2015) Biocontrol evaluation of extracts and a major component, clusianone, from Clusia fluminensis Planch \& Triana against Aedes aegypti. Memórias do Instituto Oswaldo Cruz 110: 629-635. doi: 10.1590/0074-02760150103.

Araujo AQ, Silva MT, Araujo AP (2016) Zika virus-associated neurological disorders: a review. Brain 139: 2122-2130.

Araujo HRC, Carvalho DO, Ioshino RS, Costa-da-Silva AL, Capurro ML (2015) Aedes aegypti control strategies in Brazil: incorporation of new technologies to overcome the persistence of dengue epidemics. Insects 6: 576594.

Ashfaq UA, Ahmed B (2016) De novo Structural Modeling and Conserved Epitopes Prediction of Zika Virus Envelop Protein for Vaccine Development. Viral Immunology 29:436-443.

Asif A, Manzoor S, Tuz-Zahra F, Saalim M, Ashraf M, Ishtiyaq J, Khalid M (2017) Zika Virus: Immune Evasion Mechanisms, Currently Available Therapeutic Regimens, and Vaccines. Viral Immunology 2017 Oct 13. doi: 10.1089/vim.2017.0046. [Epub ahead of print]

Atkinson B, Hearn P, Afrough B, Lumley S, Carter D, Aarons EJ, Simpson AJ, Brooks TJ, Hewson R (2016) Detection of Zika Virus in Semen. Emerging Infectious Diseases 22: 940. doi: 10.3201/eid2205.160107.

Aubry M, Richard V, Green J, Broult J, Musso D (2016) Inactivation of Zika virus in plasma with amotosalen and ultraviolet A illumination. Transfusion 56:33-40.

Awasthi S (2016) Zika Virus: Prospects for the Development of Vaccine and Antiviral Agents. Journal of Antivirals \& Antiretrovirals 8: LXI-LXIII. doi:10.4172/jaa.1000e130

Ayres CFJ (2016) Identification of Zika virus vectors and implications for control. The Lancet Infectious Diseases 16: 278-279.

Bagasra O, Addanki KC, Goodwin GR, Hughes BW, Pandey P, McLean E (2017) Cellular Targets and receptor of sexual transmission of Zika virus. Applied Immunohistochemistry and Molecular Morphology 25 :679-686. doi: 10.1097/PAI.0000000000000580.

Balasubramanian A, Teramoto T, Kulkarni AA, Bhattacharjee AK, Padmanabhan R (2016) Antiviral activities of selected antimalarials against dengue virus type 2 and Zika virus. Antiviral Research 137:141-150. DOI: https://doi.org/10.1016/j.antiviral.2016.11.015.

Barouch DH, Thomas SJ, Michael NL (2017) Prospects for a Zika virus vaccine. Immunity 46: 176-182. 
Barrows NJ, Campos RK, Powell ST, Prasanth KR, Schott-Lerner G, SotoAcosta R, Galarza-Muñoz G, McGrath EL, Urrabaz-Garza R, Gao J, Wu P, Menon R, Saade G, Fernandez-Salas I, Rossi SL, Vasilakis N, Routh A, Bradrick SS, Garcia-Blanco MA (2016) A screen of FDA-approved drugs for inhibitors of Zika virus infection. Cell Host \& Microbe 20: 259-270. Doi: 10.1016/j.chom.2016.07.004.

Barzon L, Pacenti M, Berto A, Sinigaglia A, Franchin E, Lavezzo E, Brugnaro P, Palu G (2016) Isolation of infectious Zika virus from saliva and prolonged viral RNA shedding in a traveller returning from the Dominican Republic to Italy, January 2016. Euro Surveill 21:30159.

Benelli G (2016) Spread of Zika virus: The key role of mosquito vector control. Asian Pacific Journal of Tropical Biomedicine 6:468-471.

Benelli G, Rajeswary M, Govindarajan M (2016) Towards green oviposition deterrents? Effectiveness of Syzygium lanceolatum (Myrtaceae) essential oil against six mosquito vectors and impact on four aquatic biological control agents. Environmental Science and Pollution Research (Online first 5 Dec 2016). doi: 10.1007/s11356-016-8146-3.

Benzekri R, Belfort Jr, R, Ventura CV, de Paula FB, Maia M, Leite M, Labetoulle M, Rousseau A (2017) Ocular manifestations of Zika virus: What we do and do not know. Journal Francais D'ophtalmologie 40 : 138145 .

Besnard M, Lastere S, Teissier A, Cao-Lormeau V, Musso D (2014) Evidence of perinatal transmission of Zika virus, French Polynesia, December 2013 and February 2014. Euro Surveill 19:1-4.

Bian G, Joshi D, Dong Y, Lu P, Zhou G, Pan X, Xu Y, Dimopoulos G, Xi Z (2013) Wolbachia invades Anopheles stephensi populations and induces refractoriness to Plasmodium infection. Science 340: 748-751.

Bingham AM, Cone M, Mock V, Heberlein-Larson L, Stanek D, Blackmore C, Likos A (2016) Comparison of Test Results for Zika Virus RNA in Urine, Serum, and Saliva Specimens from Persons with TravelAssociated Zika Virus Disease - Florida, 2016. Morbidity and Mortality Weekly Report 65:475-478.

Blecher K, Nasir A, Friedman A (2011) The growing role of nanotechnology in combating infectious disease. Virulence 2:395-401.

Blümel J, Musso D, Teitz S, Miyabayashi T, Boller K, Schnierle BS, Baylis SA (2016) Inactivation and removal of Zika virus during manufacture of plasma derived medicinal products. Transfusion 57: 790796. doi: 10.1111/trf.13873.

Boggild AK, Geduld J, Libman M, Yansouni CP, McCarthy AE, Hajek J, Ghesquiere W, Mirzanejad Y, Vincelette J, Kuhn S, Plourde PJ, Chakrabarti S, Freedman DO, Kain KC (2017) Surveillance report of Zika virus among Canadian travellers returning from the Americas. Canadian Medical Association Journal 189 : E334-E340. DOI: 10.1503/cmaj.161241

Bonin CR, Fernandes GC, Dos Santos RW, Lobosco M (2017) Mathematical modeling based on ordinary differential equations: a promising approach to vaccinology. Human Vaccines \& Immunotherapeutics 13: 484-489. DOI: http://dx.doi.org/10.1080/21645515.2017.1264774

Bourtzis K, Dobson SL, Xi Z, Rasgon JL, Calvitti M, Moreira LA, Bossin HC, Moretti R, Baton LA, Hughes GL, Mavingui P, Gilles JR (2014) Harnessing mosquito-Wolbachia symbiosis for vector and disease control. Acta Tropica 132 (Suppl): S150-S163. doi: https://doi.org/10.1016/j.actatropica.2013.11.004.

Bowatte G, Perera P, Senevirathne G, Meegaskumbura S, Meegaskumbura M (2013) Tadpoles as dengue mosquito (Aedes aegypti) egg predators. Biological Control 67: 469-474. doi: 10.1016/j.biocontrol.2013.10.005.
Boyer Chammard TH, Schepers K, Breurec S, Messiaen T, Destrem AL, Mahevas M, Soulillou A, Janaud L, Curlier E, Herrmann-Storck C, Hoen B (2017) Severe thrombocytopenia after Zika virus infection, Guadeloupe, 2016. Emerging Infectious Diseases 23: 696-698. doi: 10.3201/eid2304.161967.

Brasil P, Pereira JP Jr, Moreira ME, Ribeiro Nogueira RM, Damasceno L, Wakimoto M, Rabello RS, Valderramos SG, Halai UA, Salles TS, Zin AA, Horovitz D, Daltro P, Boechat M, Raja Gabaglia C, Carvalho de Sequeira P, Pilotto JH, Medialdea-Carrera R, Cotrim da Cunha D, Abreu de Carvalho LM, Pone M, Machado Siqueira A, Calvet GA, Rodrigues Baião AE, Neves ES, Nassar de Carvalho PR, Hasue RH, Marschik PB, Einspieler C, Janzen C, Cherry JD, Bispo de Filippis AM, Nielsen-Saines K (2016) Zika Virus Infection in Pregnant Women in Rio de Janeiro. The New England Journal of Medicine 375:2321-34.

Brown C (2015) Zika virus outbreaks in Asia and South America. Canadian Medical Association Journal 188:1. doi: 10.1503/cmaj.109-5212.

Bullard-Feibelman KM, Govero J, Zhu Z, Salazar V, Veselinovic M, Diamond MS, Geiss BJ (2017) The FDA-approved drug sofosbuvir inhibits Zika virus infection. Antiviral Research 137:134-140. doi: 10.1016/j.antiviral.2016.11.023.

Bullerdiek J, Dotzauer A, Bauer I (2016) The mitotic spindle: linking teratogenic effects of Zika virus with human genetics? . Molecular cytogenetics 9: 32. doi:10.1186/s13039-016-0240-1.

Butler T, Cho A, Kim CU, Xu J (2001) Carba-nucleoside analogs for antiviral treatment. US8012942B2. Washington, DC: U.S. Patent and Trademark Office.

Byler KG, Ogungbe IV, Setzer WN (2016) In-silico screening for anti-Zika virus phytochemicals. Journal of Molecular Graphics and Modelling 69:78-91. DOI: https://doi.org/10.1016/j.jmgm.2016.08.011.

Byler KG, Setzer WN (2016) In-silico screening for anti-Zika virus phytochemicals. Planta Medica 81:S1-S381. DOI: DOI: $10.1055 / \mathrm{s}-$ 0036-1596272.

Callaway E (2016) Rio fights Zika with biggest release yet of bacteriainfected mosquitoes. Nature 539: 17-18.

Calvet G, Aguiar RS, Melo ASO, Sampaio SA, de Filippis I, Fabri A, Araujo ESM, de Sequeira PC, de Mendonça MCL, de Oliveira L, Tschoeke DA, Schrago CG, Thompson FL, Brasil P, dos Santos FB, Nogueira RMR, Tanuri A, de Filippis AMB (2016b) Detection and sequencing of Zika virus from amniotic fluid of fetuses with microcephaly in Brazil: a case study. The Lancet Infectious Diseases $16: 653-660$.

Calvet GA, Filippis AM, Mendon,ca MC, Sequeira PC, Siqueira AM, Veloso VG, Nogueira RM, Brasil P (2016a) First detection of autochthonous Zika virus transmission in a HIV-infected patient in Rio de Janeiro. Journal of Clinical Virology 74:1-3. DOI: https://doi.org/10.1016/j.jcv.2015.11.014.

Calvert AE, Biggerstaff BJ, Tanner NA, Lauterbach M, Lanciotti RS (2017) Rapid colorimetric detection of Zika virus from serum and urine specimens by reverse transcription loop-mediated isothermal amplification (RT-LAMP). PLoS One. 12:e0185340.

Campos GS, Bandeira AC, Sardi SI (2015) Zika virus outbreak, Bahia, Brazil. Emerging Infectious Diseases 21:1885-1886.

Cao RY, Xu YF, Zhang TH, Yang JJ, Yuan Y, Hao P, Shi Y, Zhong J, Zhong W (2017) Pediatric Drug Nitazoxanide: A Potential Choice for Control of Zika. In Open Forum Infectious Diseases 4: doi: 10.1093/ofid/ofx009. eCollection 2017 Winter. 
Cao-Lormeau VM, Blake A, Mons S, Lastere S, Roche C, Vanhomwegen J, Dub T, Baudouin L, Teissier A, Larre P, Vial AL, Decam C, Choumet V, Halstead SK, Willison HJ, Musset L, Manuguerra JC, Despres P, Fournier E, Mallet HP, Musso D, Fontanet A, Neil J, Ghawché F (2016) Guillain-Barré syndrome outbreak associated with Zika virus infection in French Polynesia: a case-control study. The Lancet 387: 1531-1539.

Cao-Lormeau VM, Roche C, Teissier A, Robin E, Berry AL, Mallet HP, Sall AA, Musso D (2014) Zika virus, French polynesia, South pacific, 2013 [Letter]. Emerging Infectious Diseases 20:1085-1086. doi: 10.3201/eid2006.140138.

Caragata EP, Dutra HL, Moreira LA (2016) Exploiting intimate relationships: Controlling mosquito-transmitted disease with Wolbachia. Trends in Parasitology 32: 207-218. DOI: http://dx.doi.org/10.1016/j.pt.2015.10.011.

Carneiro BM, Batista MN, Braga ACS, Nogueira ML, Rahal P (2016) The green tea molecule EGCG inhibits Zika virus entry. Virology 496:215-218.

Carneiro LA, Travassos LH (2016) Autophagy and viral diseases transmitted by Aedes aegypti and Aedes albopictus. Microbes and Infection 18:169-171. DOI: https://doi.org/10.1016/j.micinf.2015.12.006.

Cauchemez S, Besnard M, Bompard P, Dub T, Guillemette-Artur P, Eyrolle-Guignot D, Salje H, Van Kerkhove MD, Abadie V, Garel C, Fontanet A, Henri-Pierre M (2016) Association between Zika virus and microcephaly in French Polynesia, 2013-15: a retrospective study. The Lancet 387:2125-32.

CDC (2016) Revised diagnostic testing for Zika, chikungunya, and dengue viruses in US Public Health Laboratories Centers for Disease Control, Division of Vector-Borne Diseases, 20167 February 2016. Report No.

Chan JF, Choi GK, Yip CC, Cheng VC, Yuen KY (2016) Zika fever and congenital Zika syndrome: An unexpected emerging arboviral disease. Journal of Infection 72: 507-524. http://linkinghub.elsevier.com/retrieve/pii/S016344531600061X.

Chan JFW, Chik KK, Yuan S, Yip CCY, Zhu Z, Tee KM, Tsang JO, Chan CC, Poon VK, Lu G, Zhang AJ, Lai KK, Chan KH, Kao RY, Yuen KY, Zhang AJ (2017a) Novel antiviral activity and mechanism of bromocriptine as a Zika virus NS2B-NS3 protease inhibitor. Antiviral Research 141:29-37.

Chan JFW, Yip CC, Tee KM, Zhu Z, Tsang JO, Chik KK, Tsang TG, Chan CC, Poon VK, Sridhar S, Yin F, Hung IF, Chau SK, Zhang AJ, Chan $\mathrm{KH}$, Yuen KY (2017b) Improved detection of Zika virus RNA in human and animal specimens by a novel, highly sensitive and specific real-time RT-PCR assay targeting the 5'-untranslated region of Zika virus. Tropical Medicine and International Health 22: 594-603. doi: 10.1111/tmi.12857.

Chandramohan B, Murugan K, Panneerselvam C, Madhiyazhagan P, Chandirasekar R, Dinesh D, Kumar PM, Kovendan K, Suresh U, Subramaniam J, Rajaganesh R, Aziz AT, Syuhei B, Alsalhi MS, Devanesan S, Nicoletti M, Wei H, Benelli G (2016) Characterization and mosquitocidal potential of neem cake-synthesized silver nanoparticles: genotoxicity and impact on predation efficiency of mosquito natural enemies. Parasitology Research 115: 1015-1025. doi: 10.1007/s00436-0154829-9.

Chang C, Ortiz K, Ansari A, Gershwin ME (2016) The Zika outbreak of the 21st century. Journal of Autoimmunity 68:1-13.

Charrel RN, Leparc-Goffart I, Pas S, Lamballerie X, Koopmans M, Reusken C (2016) State of knowledge on Zika virus for an adequate laboratory response. Bulletin of the World Health Organization 94:574584. doi:10.2471/BLT.16.171207.
Chen LH, Hamer DH (2016) Zika virus: rapid spread in the western hemisphere. Annals of Internal Medicine 164:613-615. doi:10.7326/M160150 .

Chen LH, Wilson ME (2010) Dengue and chikungunya infections in travelers. Current Opinion in Infectious Diseases 23:438-444.

Cheng F, Murray JL, Rubin DH (2016) Drug repurposing: new treatments for Zika virus infection? Trends in Molecular Medicine 22 :919-921. doi: 10.1016/j.molmed.2016.09.006.

Chiang C, Beljanski V, Yin K, Olagnier D, Ben Yebdri F, Steel C, Goulet ML, DeFilippis VR, Streblow DN, Haddad EK, Trautmann L, Ross T, Lin R, Hiscott J (2015) Sequence-Specific Modifications Enhance the Broad spectrum Antiviral Response Activated by RIG-I Agonists. Journal of Virology 89:8011-25.

Chitti SV, Prasad AK, Saxena SK (2016) Emerging Zika virus disease: a public health emergency of global concern. Virus Disease 27: 211-214.

Clark KB, Onlamoon N, Hsiao HM, Perng GC, Villinger F (2013) Can non-human primates serve as models for investigating dengue disease pathogenesis? Frontiers in Microbiology 4: 305.

Conde JN, da Silva EM, Allonso D, Coelho DR, Andrade ID, de Medeiros LN, Menezes JL, Barbosa AS, Mohana-Borges R (2016) Inhibition of the membrane attack complex by dengue NS1 through interaction with vitronectin and terminal complement proteins. Journal of Virology 90: 9570-9581.

Contreras D, Arumugaswami V (2016) Zika virus infectious cell culture system and the in vitro prophylactic effect of interferons. Journal of Visualized Experiments 114:e54767-e54767.

Cordeiro MT, Brito CA, Pena LJ, Castanha P, Gil LH, Lopes KG, Dhalia R, Meneses JA, Ishigami AC, Mello LM, Alencar LX, Guarines KM, Rodrigues LC, Marques ET (2016) Results of a Zika Virus (ZIKV) Immunoglobulin M-specific diagnostic assay are highly correlated with detection of neutralizing anti-ZIKV antibodies in neonates with congenital disease. The Journal of Infectious Diseases 214: 1897-1904.

Costa VV, Del Sarto JL, Rocha RF, Silva FR, Doria JG, Olmo IG, Marques RE, Queiroz-Junior CM, Foureaux G, Araújo JMS, Cramer A, Real ALCV, Ribeiro LS, Sardi SI, Ferreira AJ, Machado FS, de Oliveira AC, Teixeira AL, Nakaya HI, Souza DG, Ribeiro FM, Teixeira MM (2017) N-Methyl-d-Aspartate (NMDA) Receptor Blockade Prevents Neuronal Death Induced by Zika Virus Infection. mBio 8 : e00350-17.

Coutard B, Barral K, Lichière J, Selisko B, Martin B, Aouadi W Lombardiac MO, Debartd F, Vasseurd JJ, Guillemota JC, Canarda B, Decrolya E (2017) The Zika virus methyltransferase: structure and functions for drug design perspectives. Journal of Virology 91: e02202-16. doi: 10.1128/JVI.02202-16.

Coutinho-Abreu IV, Ramalho-Ortigao M (2010) Transmission blocking vaccines to control insect-borne diseases: a review. Memorias do Instituto Oswaldo Cruz 105: 1-12. doi: 10.1590/S0074-02762010000100001.

Cuevas EL, Tong VT, Rozo N, Valencia D, Pacheco O, Gilboa SM, Mercado M, Renquist CM, González M, Ailes EC, Duarte C, Godoshian V, Sancken CL, Turca AM, Calles DL, Ayala M, Morgan P, Perez EN, Bonilla HQ, Gomez RC, Estupiñan AC, Gunturiz ML, Meaney-Delman D, Jamieson DJ, Honein MA, Martínez ML (2016) Preliminary Report of Microcephaly Potentially Associated with Zika Virus Infection During PregnancyĐColombia, January- November 2016. Morbidity and Mortality Weekly Report 65:1409-13.

D'Ortenzio E, Matheron S, de Lamballerie X, Hubert B, Piorkowski G, Maquart M Descamps D, Damond F, Leparc-Goffart I (2016) Evidence of 
sexual transmission of Zika virus. The New England Journal of Medicine 374: 2195-2198.

Dai L, Song J, Lu X, Deng YQ, Musyoki AM, Cheng H, Zhang Y, Yuan Y, Song H, Haywood J, Xiao H, Yan J, Shi Y, Qin CF, Qi J, Gao GF (2016) Structures of the Zika Virus Envelope Protein and Its Complex with a Flavivirus Broadly Protective Antibody. Cell Host \& Microbe 19: 696704.

Dang J, Tiwari SK, Lichinchi G, Qin Y, Patil VS, Eroshkin AM, Rana TM (2016) Zika virus depletes neural progenitors in human cerebral organoids through activation of the innate immune receptor TLR3. Cell Stem Cell 19:258-65.

Darbellay J, Lai K, Babiuk S, Berhane Y, Ambagala A, Wheler C, Wilson D, Walker S, Potter A, Gilmour M, Safronetz D, Gerdts V, Karniychuk U (2017) Neonatal pigs are susceptible to experimental Zika virus infection. Emerging Microbes \& Infections 6:e6. doi: 10.1038/emi.2016.133.

Dasti JI (2016) Zika virus infections: An overview of current scenario. Asian Pacific Journal of Tropical Medicine 9 : 621-625.

de Araújo TVB, Rodrigues LC, de Alencar Ximenes RA, de Barros Miranda-Filho D, Montarroyos UR, de Melo APL, Valongueiro S, de Albuquerque MFPM, Souza WV, Braga C, Filho SPB, Cordeiro MT, Vazquez E, Di Cavalcanti Souza Cruz D, Henriques CMP, Bezerra LCA, da Silva Castanha PM, Dhalia R, Marques-Júnior ETA, Martelli CMT; investigators from the Microcephaly Epidemic Research Group; Brazilian Ministry of Health; Pan American Health Organization; Instituto de Medicina Integral Professor Fernando Figueira; State Health Department of Pernambuco (2016) Association between Zika virus infection and microcephaly in Brazil, January to May, 2016: preliminary report of a case-control study. The Lancet Infectious Diseases 16:1356-63.

de Wispelaere M, Carocci M, Liang Y, Liu Q, Sun E, Vetter ML, Wang J, Gray NS, Yang PL (2016) Discovery of host-targeted covalent inhibitors of dengue virus. Antiviral Research 139:171-179. doi: 10.1016/j.antiviral.2016.12.017.

Dejnirattisai W, Supasa P, Wongwiwat W, Rouvinski A, Barba-Spaeth G, Duangchinda T, Sakuntabhai A, Cao-Lormeau VM, Malasit P, Rey FA, Mongkolsapaya J, Screaton GR (2016) Dengue virus sero-cross-reactivity drives antibody-dependent enhancement of infection with zika virus. Nature Immunology 17:1102-1108.

Delvecchio R, Higa LM, Pezzuto P, Valadão AL, Garcez PP, Monteiro FL, Loiola EC, Dias AA, Silva FJ, Aliota MT, Caine EA, Osorio JE, Bellio M, O'Connor DH, Rehen S, de Aguiar RS, Savarino A, Campanati L, Tanuri A (2016) Chloroquine, an endocytosis blocking agent, inhibits Zika virus infection in different cell models. Viruses 8: E322.

Deng Y, Zeng L, Bao W, Xu P, Zhong G (2016b) Experience of integrated traditional Chinese and Western medicine in first case of imported Zika virus disease in China. Zhonghua Wei Zhong Bing ji Jiu Yi Xue 28:106-109.

Deng YQ, Zhang NN, Li CF, Tian M, Hao JN, Xie XP, Shi PY, Qin CF (2016a) Adenosine analog NITD008 is a potent inhibitor of Zika virus. In Open Forum Infectious Diseases 3: ofw175.

Devnarain N, Pritia Ramharack P, Soliman ME (2017) Brain grants permission of access to Zika virus but denies entry to drugs: a molecular modeling perspective to infiltrate the boundary. RSC Advances 7: 4741647424. DOI: $10.1039 / \mathrm{C} 7 \mathrm{RA} 05918 \mathrm{C}$

Dhama K, Chakraborty S, Tiwari R, Verma AK, Saminathan M, Amarpal, Malik YS, Nikousefat Z, Javdani M, Khan RU (2014b) A concept paper on novel technologies boosting production and safeguarding health of humans and animals. Research Opinion in Animal and Veterianry Sciences $4: 353$ 370 .

Dhama K, Chakraborty S, Wani MY, Verma AK, Deb R, Tiwari R, Kapoor S (2013C) Novel and emerging therapies safeguarding health of humans and their companion animals: A review. Pakistan Journal of Biological Sciences 16: 101-111.

Dhama K, Karthik K, Chakraborty S, Tiwari R, Kapoor S, Kumar A, Thomas P (2014a) Loop-mediated isothermal amplification of DNA (LAMP) - a new diagnostic tool lights the world of diagnosis of Animal and Human Pathogens: A review. Pakistan Journal of Biological Sciences 17: 151-166.

Dhama K, Latheef SK, Munjal AK, Khandia R, Samad HA, Iqbal HMN, Joshi SK (2016) Probiotics in curing allergic and inflammatory conditions - Research Progress and futuristic vision. Recent Patents on Inflammation \& Allergy Drug Discovery 10: 105-118. doi: 10.2174/1872213X10666161226162229.

Dhama K, Malik YS, Malik SV, Singh RK (2015) Ebola from emergence to epidemic: the virus and the disease, global preparedness and perspectives. The Journal of Infection in Developing Countries 9:441-455.

Dhama K, Tiwari R, Chakraborty S, Kumar A, Karikalan M, Singh R, Rai RB (2013a) Global warming and emerging infectious diseases of animals and humans: current scenario, challenges, solutions and future perspectives - a review. International Journal of Current Research 5: 1942-1958.

Dhama K, Verma AK, Tiwari R, Chakraborty S, Vora K, Kapoor S, Deb R, Karthik K, Singh R, Munir M, Natesan S (2013b) A perspective on applications of geographical information system (GIS); an advanced tracking tool for disease surveillance and monitoring in veterinary epidemiology. Advances in Animal and Veterinary Sciences 1: 14-24.

Dhama K, Karthik K, Khandia R, Munjal A, Tiwari R, Rana R, Khurana SK, Khan RU, Alagawany M, Farag MR, Dadar M, Joshi SK (2018). Medicinal and therapeutic potential of herbs and plant metabolites / extracts countering viral pathogens - Current knowledge and future prospects. Current Drug Metabolism 2018 Jan 29. doi: 10.2174/1389200219666180129145252. [Epub ahead of print]

Dhiman RC, Pahwa S, Dhillon GP, Dash AP (2010) Climate change and threat of vector-borne diseases in India: are we prepared? Parasitology Research106:763-773.

Diamond MS, Pierson TC, Fremont DH (2008) The structural immunology of ontibody protection against West Nile Virus. Immunological Reviews 225: 212-225. doi: 10.1111/j.1600-065X.2008.00676.x

Dick GW (1952) Zika virus. II. Pathogenicity and physical properties. Transactions of the Royal Society of Tropical Medicine and Hygiene 46:521-534. DOI: https://doi.org/10.1016/0035-9203(52)90043-6

Dickson LB, Sanchez-Vargas I, Sylla M, Fleming K, Black WC (2014) Vector competence in West African Aedes aegypti is flavivirus species and genotype dependent. PLoS Neglected Tropical Diseases 8:e3153. doi: 10.1371/journal.pntd.0003153.

Ding S, Greenberg HB (2017) Zika mRNA vaccine induces long-term protective immunity. AME Medical Journal DOI: 10.21037/amj.2017.05.22.

Dos Santos T, Rodriguez A, Almiron M, Sanhueza A, Ramon P, de Oliveira WK, Coelho GE, Badaró R, Cortez J, Ospina M, Pimentel R, Masis R, Hernandez F, Lara B, Montoya R, Jubithana B, Melchor A, Alvarez A, Aldighieri S, Dye C, Espinal MA (2016) Zika Virus and the Guillain-Barre SyndromeĐCase Series from Seven Countries. The New England Journal of Medicine 375:1598-601. 
Dowd KA, DeMaso CR, Pelc RS, Speer SD, Smith AR, Goo L, Platt DJ, Mascola JR, Graham BS, Mulligan MJ, Diamond MS, Ledgerwood JE, Pierson TC (2016b) Broadly neutralizing activity of Zika virus-immune sera identifies a single viral serotype. Cell Reports 16:1485-1491. DOI: http://dx.doi.org/10.1016/j.celrep.2016.07.049.

Dowd KA, Ko SY, Morabito KM, Yang ES, Pelc RS, DeMaso CR, Castilho LR, Abbink P, Boyd M, Nityanandam R, Gordon DN, Gallagher J, Chen X, Todd JP, Tsybovsky Y, Harris A, Huang YJS, Higgs S, Vanlandingham DL, Andersen H, Lewis MG, Barrera RDL, Eckels KH, Jarman RG, Nason MC, Barouch DH, Roederer M, Kong WP, Mascola JR, Pierson TC, Graham BS (2016a) Rapid development of a DNA vaccine for Zika virus. Science 354: 237-240.

Duan W, Song H, Wang H, Chai Y, Su C, Qi J, Shi Y, Gao GF (2017) The crystal structure of Zika virus NS5 reveals conserved drug targets. The EMBO Journal 36:919-933.

Dudley DM, Aliota MT, Mohr EL, Weiler AM, Lehrer-Brey G, Weisgrau KL, Mohns MS, Breitbach ME, Rasheed MN, Newman CM, Gellerup DD, Moncla LH, Post J, Schultz-Darken N, Schotzko ML, Hayes JM, Eudailey JA, Moody MA, Permar SR, O'Connor SL, Rakasz EG, Simmons HA, Capuano S, Golos TG, Osorio JE, Friedrich TC, O'Connor DH (2016) A rhesus macaque model of Asian-lineage Zika virus infection. Nature Communication 7:12204. doi:10.1038/ncomms12204.

Duffy MR, Chen TH, Hancock WT, Powers AM, Kool JL, Lanciotti RS, Pretrick M, Marfel M, Holzbauer S, Dubray C, Guillaumot L, Griggs A, Bel M, Lambert AJ, Laven J, Kosoy O, Panella A, Biggerstaff BJ, Fischer M, Hayes EB (2009) Zika virus outbreak on Yap Island, Federated States of Micronesia. The New England Journal of Medicine 360:2536-2543. doi: 10.1056/NEJMoa0805715.

Duhaime-Ross A (2016) Zika linked to more birth defects than just microcephaly. The verge, 2016. [Online] Available from: http://www.theverge.com/2016/3/8/11181088/zika-birth-defects-fetaldeath-growth-retardation-who [Accessed on 9 March 2016].

Duong V, Ong S, Leang R, Huy R, Ly S, Mounier U, Ou T, In S, Peng B, Ken S, Buchy P, Tarantola A, Horwood PF, Dussart P (2017) Low circulation of Zika virus, Cambodia, 2007-2016. Emerging Infectious Diseases 23: 296-299.

Dupont-Rouzeyrole M, Biron A, O'Connor O, Huguon E, Descloux E (2016) Infectious Zika viral particles in breast milk. The Lancet 387:1051. Doi: 10.1016/S0140-6736(16)00624-3.

Dutra HLC, Rocha MN, Dias FBS, Mansur SB, Caragata EP, Moreira LA (2016) Cell Host and Microbe. Wolbachia blocks currently circulating zika virus isolates in Brazilian Aedes aegypti Mosquitoes 19: 771-774.

Dyer O (2016a) Zika vaccine could be in production by year's end, says maker. BMJ 352: i630.

Dyer O (2016b) Trials of Zika vaccine are set to begin in North America. BMJ 353:i3588.

Eboigbodin KE, Brummer M, Ojalehto T, Hoser M (2016) Rapid molecular diagnostic test for Zika virus with low demands on sample preparation and instrumentation. Diagnostic Microbiology and Infectious Disease 86:369-371. doi:10.1016/j.diagmicrobio.2016.08.027.

Ekins S, Perryman AL, Andrade CH (2016) OpenZika: An IBM World Community Grid Project to Accelerate Zika Virus Drug Discovery. PLOS Neglected Tropical Diseases 10:e005023.

Elgot J (2016) France records first sexually transmitted case of Zika in Europe. The guardian 2016. [Online] Available from: http://www.theguardian.com/world/2016/feb/27/zika-france-records-firstsexually-transmitted-case-europe [Accessed on 28 February 2016].

Epelboin S, Dulioust E, Epelboin L, Benachi A, Merlet F, Patrat C (2017) Zika virus and reproduction: facts, questions and current management. Human Reproduction Update 9:1-17.

European Centre for Disease Prevention and Control (2016) Rapid risk assessment. Zika virus disease epidemic: potential association with microcephaly and Guillain-Barré syndrome. Second update, 8 February 2016. Stockholm: ECDC; 2016.

Eyer L, Nencka R, Huvarová I, Palus M, Alves MJ, Gould EA, De Clercq E, Růžek D (2016) Nucleoside inhibitors of Zika virus. The Journal of Infectious Diseases 214:707-11. doi: 10.1093/infdis/jiw226.

Fagbami AH (1979) Zika virus infections in Nigeria: virological and seroepidemiological investigations in Oyo State. The Journal of Hygiene 83:213-219.

Faizan MI, Abdullah M, Ali S, Naqvi IH, Ahmed A, Parveen S (2016) Zika Virus-Induced Microcephaly and Its Possible Molecular Mechanism. Intervirology 59: 152-158.

Farcet MR, Kreil TR (2017) Zika virus is not thermostable: very effective virus inactivation during heat treatment (pasteurization) of human serum albumin. Transfusion 57 :797-801. doi: 10.1111/trf.13953.

Fauci AS, Morens DM (2016) Zika virus in the Americas - yet another Arbovirus threat. The New England Journal of Medicine 374:601-604.

Faye O, Faye O, Dupressoir A, Weidmann M, Ndiaye M, Alpha Sall A (2008) One-step RT-PCR for detection of Zika virus. Journal of Clinical Virology 43:96-101. DOI: http://dx.doi.org/10.1016/j.jcv.2008.05.005

Faye O, Freire CC, Iamarino A, Faye O, de Oliveira JV, Diallo M, Zanotto PMA, Sall AA (2014) Molecular evolution of Zika virus during its emergence in the 20(th) century. PLoS Neglected Tropical Diseases 8:e2636. doi: 10.1371/journal.pntd.0002636.

Feranchuk S, Potapova U, Belikov S (2016) Virtual screening of inhibitors for the Zika virus proteins. Available on http://biorxiv.org/content/biorxiv/early/2016/06/27/060798.full.pdf doi:http://dx.doi.org/10.1101/060798.

Ferguson NM, Cucunuba ZM, Dorigatti I, Nedjati-Gilani GL, Donnelly CA, Basanez MG, Nouvellet P, Lessler J (2016) EPIDEMIOLOGY. Countering the Zika epidemic in Latin America. Science 353: 353-354.

Fernandez E, Diamond MS (2017) Vaccination strategies against Zika virus. Current Opinion in Virology 23:59-67. DOI: https://doi.org/10.1016/j.coviro.2017.03.006.

Fernando S, Fernando T, Stefanik M, Eyer L, Ruzek D (2016) An approach for Zika virus inhibition using homology structure of the envelope protein. Mol Biotechnol 58:801-806.

Fonseca K, Meatherall B, Zarra D, Drebot M, MacDonald J, Pabbaraju K, Wong S, Webster P, Lindsay R, Tellier R (2014) First case of Zika virus infection in a returning Canadian traveler. The American Journal of Tropical Medicine and Hygiene 91:1035-1038.

Food and Drug Administration. Recommendations for donor screening, deferral, and product management to reduce the risk of transfusiontransmission of Zika virus. Guidance for industry. FDA; 2016. Available at:

http://www.fda.gov/downloads/BiologicsBloodVaccines/GuidanceComplia nce RegulatoryInformation/Guidances/Blood/UCM486360.pdf. Accessed on $01 / 03 / 2016$. 
Franchini M, Velati C (2015) Blood safety and zoonotic emerging pathogens: now it's the turn of Zika virus! Blood Transfus 14:93-94.

Franke T (2008) PI3K/Akt: getting it right matters. Oncogene 27:6473.

Freire CCDM, Iamarino A, Neto DFDL, Sall AA, Zanotto PMDA (2015) Spread of the pandemic Zika virus lineage is associated with NS1 codon usage adaptation in humans. BioRxiv 032839 doi: http://dx.doi.org/10.1101/032839.

Gatherer D, Kohl A (2016) Zika virus: a previously slow pandemic spreads rapidly through the Americas. Journal of General Virology 97: 269-273.

Gautret P, Simon F (2016) Dengue, chikungunya and Zika and mass gatherings: what happened in Brazil, 2014. Travel Medicine and Infectious Disease 14:7-8.

George J, Valiant WG, Mattapallil MJ, Walker M, Huang YS, Vanlandingham DL, Misamore J, Greenhouse J, Deborah E. Weiss, Daniela Verthelyi, Stephen Higgs, Hanne Andersen, Mark G. Lewis, Mattapallil JJ (2017) Prior Exposure to Zika Virus Significantly Enhances Peak Dengue-2 Viremia in Rhesus Macaques. Scientific Reports 7: 10498

George KS, Pinsky BA (2018) Molecular diagnosis of Zika virus infections. Reviews in Medical Microbiology 29 : 8-16.

Gold CA, Josephson SA (2016) Anticipating the challenges of Zika virus and the incidence of Guillain-Barré syndrome. JAMA Neurology 73:9056.

Goncalvez AP, Engle RE, St Claire M, Purcell RH, Lai CJ (2007) Monoclonal antibody-mediated enhancement of dengue virus infection in vitro and in vivo and strategies for prevention. Proceedings of the National Academy of Sciences $104: 9422-7$.

Goorhuis A, von Eije KJ, Douma RA, Rijnberg N, van Vugt M, Stijnis C, Grobusch MP (2016) Zika virus and the risk of imported infection in returned travelers: implications for clinical care. Travel Medicine and Infectious Disease 14:13-15.

Gould EA, Buckley A (1989) Antibody-dependent enhancement of yellow fever and Japanese encephalitis virus neurovirulence. Journal of General Virology $70: 1605-1608$

Gourinat AC, O’Connor O, Calvez E, Goarant C, Dupont-Rouzeyrol M (2015) Detection of Zika virus in urine. Emerging Infectious Diseases 21:84-86. doi: 10.3201/eid2101.140894.

Govindarajan M, Hoti SL, Benelli G (2016) Facile fabrication of ecofriendly nano-mosquitocides: Biophysical characterization and effectiveness on neglected tropical mosquito vectors. Enzyme and Microbial Technology 95:155-163.

Granger D, Hilgart H, Misner L, Christensen J, Bistodeau S, Palm J, Strain AK, Konstantinovski M, Liu D, Tran A, Theel ES (2017) Serologic Testing for Zika Virus: Comparison of Three Zika Virus IgM ELISAs and Initial Laboratory Experiences. Journal of Clinical Microbiology pii: JCM.00580-17. doi: 10.1128/JCM.00580-17. [2017, April 26, Epub ahead of print].

Grard G, Caron M, Mombo IM, Nkoghe D, Mboui Ondo S, Jiolle D, Fontenille D, Paupy C, Leroy EM (2014) Zika virus in Gabon (Central Africa) - 2007: a new threat from Aedes albopictus? PLOS Neglected Tropical Diseases 8 :e2681.

Grifoni A, Pham J, Sidney J, O'Rourke PH, Paul S, Peters B, Martini SR, de Silva AD, Ricciardi MJ, Magnani DM, Silveira CGT, Maestri A, Costa PR, de-Oliveira-Pinto LM, de Azeredo EL, Damasco PV, Phillips E, Mallal S, de Silva AM, Collins M, Durbin A, Diehl SA, Cerpas C, Balmaseda A, Kuan G, Coloma J, Harris E, Crowe JE Jr, Stone
M, Norris PJ, Busch M, Vivanco-Cid H, Cox J, Graham BS, Ledgerwood JE, Turtle L, Solomon T, Kallas EG, Watkins DI, Weiskopf D, Sette A (2017) Prior Dengue virus exposure shapes $\mathrm{T}$ cell immunity to Zika virus in humans. Journal of Virology pii: JVI.01469-17. doi: 10.1128/JVI.01469-17.

Grischott F, Puhan M, Hatz C, Schlagenhauf P (2016) Non-vector-borne transmission of Zika virus: a systematic review. Travel medicine and infectious disease 14: 313-330.

Gulland A (2016) Zika virus is a global public health emergency, declares WHO. BMJ 352:i657.

Haddow AD, Nalca A, Rossi FD, Miller LJ, Wiley MR, Perez-Sautu U, Washington SC, Norris, SL, Wollen-Roberts SE, Shamblin JD, Kimmel AE, Bloomfield HA, Valdez, SM, Sprague TR, Principe LM, Bellanca SA, Cinkovich SS, Lugo-Roman L, Cazares LH, Pratt WD, Palacios GF, Bavari S, Pitt ML, Nasar F (2017) High infection rates for adult macaques after intravaginal or intrarectal inoculation with Zika virus. Emerging Infectious Diseases 23:8. doi: 10.3201/eid2308.170036.

Haddow AD, Schuh AJ, Yasuda CY, Kasper MR, Heang V, Huy R, Guzman H, Tesh RB, Weaver SC (2012) Genetic characterization of Zika virus strains: geographic expansion of the Asian lineage. PLoS Neglected Tropical Diseases 6: e1477.

Hajra A, Bandyopadhyay D, Hajra SK (2016) Zika virus: a global threat to humanity: a comprehensive review and current developments. North American Journal of Medical Sciences 8: 123-128.

Halstead SB, Shotwell H, Casals J (1973) Studies on the pathogenesis of dengue infection in monkeys. I. Clinical laboratory responses to primary infectionThe Journal of Infectious Diseases 128 :7-14.

Hamel R, Dejarnac O, Wichit S, Ekchariyawat P, Neyret A, Luplertlop N, Perera-Lecoina M, Surasombatpattanae P, Talignania L, Thomasa F, CaoLormeauf VM, Choumetg V, Briantc L, Desprèsh P, Amarab A, Ysseli H, Misséa D (2015) Biology of Zika virus infection in human skin cells. Journal of Virology 89: 8880-96. doi: 10.1128/JVI.00354-15.

Hampton T (2016) DNA vaccine protects monkeys against Zika virus infection. The Journal of the American Medical Association 316:1755.

Hashem MA, Shuvo MA, Arifuzzaman (2017) A Computational Approach to Design Potential Antiviral RNA for 3'UTR Post Transcriptional Gene Silencing of Different Strains of Zika Virus. Journal of Young Pharmacists 9: $23-30$

Hayes EB (2009) Zika virus outside Africa. Emerging Infectious Diseases 15:1347-1350.

Heang V, Yasuda CY, Sovann L, Haddow AD, Travassos da Rosa AP, Tesh RB, Kasper MR (2012) Zika virus infection, Cambodia, 2010 Emerging Infectious Diseases 18:349-351.

Hennessey M, Fischer M, Staples JE (2016) Zika Virus spreads to new areas - region of the Americas, May 2015-January 2016. Morbidity and Mortality Weekly Report 65:55-58.

Hennessy EJ, Parker AE, O'Neill LA (2010) Targeting Toll-like receptors: emerging therapeutics? Nature Reviews Drug Discovery 9: 293-307. doi: $10.1038 / \operatorname{nrd} 3203$.

Hercik K, Brynda J, Nencka R, Boura E (2017) Structural basis of Zika virus methyltransferase inhibition by sinefungin. Archives of Virology 162:2091-2096. doi: 10.1007/s00705-017-3345-x.

Higgs S (2016) Zika virus: emergence and emergency. Vector Borne Zoonotic Diseases 16:75-76. 
Hills SL, Russell K, Hennessey M, Williams C, Oster AM, Fischer M, Mead P (2016) Transmission of Zika virus through sexual contact with travelers to areas of ongoing transmission-continental United States, 2016. Morbidity and Mortality Weekly Report 65: 215-216. doi: 10.15585/mmwr.mm6508e2.

Honda K, Yanai H, Negishi H, Asagiri M, Sato M, Mizutani T, Shimada N, Ohba Y, Takaoka A, Yoshida N, Taniguchi T (2005) IRF-7 is the master regulator of type-I interferon-dependent immune responses. Nature 434:772-777. DOI: $10.1038 /$ nature03464.

Huang ASE, Shu PY, Yang CH (2016) A new reportable disease is born: Taiwan centers for disease control's response to emerging Zika virus infection. Journal of the Formosan Medical Association 115: 223-225.

Hubalek Z, Rudolf I, Nowotny N (2014) Arboviruses pathogenic for domestic and wild animals. Advances in Virus Research 89:201-275.

Ibrahim NK (2016) Zika virus: Epidemiology, current phobia and preparedness for upcoming mass gatherings, with examples from World Olympics and Pilgrimage. Pakistan Journal of Medical Sciences 32: 10381043.

Iqbal HM, Villalba A, Khandia R, Munjal A, Dhama K (2017) Recent trends in nanotechnology-based drugs and formulations for targeted therapeutic delivery. Recent Patents on Inflammation \& Allergy Drug Discovery 10:86-93. doi: 10.2174/1872213X10666161213162823.

Jamil Z, Waheed Y, Durrani TZ (2016) Zika virus, a pathway to new challenges-A Review. Asian Pacific Journal of Tropical Medicine 9: 626629.

Junquera EC, Mateos-Hern_andez L, de la Fuente J, de la Lastra JM (2014) Recent advances in the development of anti-Infective prophylactic and/or therapeutic agents based on toll-like receptor (TLRs). Recent Patents on Anti-Infective Drug Discovery 9:14-24.

Kaddumukasa MA, Mutebi JP, Lutwama JJ, Masembe C, Akol AM (2014) Mosquitoes of Zika forest, Uganda: species composition and relative abundance. Journal of Medical Entomology 51: 104-113.

Kaushik A, Tiwari S, Jayant RD, Vashist A, Nikkhah-Moshaie R, El-Hage N, Nair M (2017) Electrochemical biosensors for early stage Zika diagnostics. Trends in Biotechnology, 35: 308-317.

Kawadkar J, Chauhan MK, Maharana M (2011) Nanobiotechnology: application of nanotechnology in diagnosis, drug discovery and drug development. Asian Journal of Pharmaceutical and Clinical Research 4:2328.

Kawiecki AB, Christofferson RC (2016) Zika virus-induced antibody response enhances dengue virus serotype 2 replication in vitro. Journal of Infectious Diseases 214 :1357-1360.

Keasey SL, Pugh CL, Jensen SM, Smith JL, Hontz RD, Durbin AP, Dudley DM, O'Connor DH, Ulrich RG (2017) Antibody Responses to Zika Virus Infections in Environments of Flavivirus Endemicity. Clinical and Vaccine Immunology 24: pii: e00036-17. doi: 10.1128/CVI.00036-17.

Kelvin AA, Banner D, Pamplona L, Alencar C, Rubino S, Heukelbach J (2016) ZIKATracker: a mobile App for reporting cases of ZIKV worldwide. The Journal of Infection in Developing Countries 10:113-115.

Kennedy RB (2011) Pushing forward with Zika vaccines. EBioMed 13:2930 .

Kennedy RB, Poland GA (2011) The top five "game changers" in vaccinology: toward rational and directed vaccine development. Omics 15:533-537.
Khandia R, Munjal A, Dhama K (2017) Consequences of Zika virus infection during fetal stage and pregnancy safe drugs: an update. International Journal of Pharmacology 13: 370-377.

Kim E, Erdos G, Huang S, Kenniston T, Falo LD, Gambotto A (2016) Preventative vaccines for Zika virus outbreak: preliminary evaluation. EBioMedicine 13: 315-320.

Koenig KL, Almadhyan A, Burns MJ (2016) Identify-isolate-inform: a tool for initial detection and management of Zika virus patients in the emergency department. The Western Journal of Emergency Medicine 17: 238-244. doi: 10.5811/westjem. 2016.3.30188.

Koff WC, Burton DR, Johnson PR, Walker BD, King CR, Nabel GJ, Ahmed R, Bhan MK, Plotkin SA (2013) Accelerating next generation vaccine development for global disease prevention. Science 340: 1232910.

Kollars TM (2016) Reducing the risk of Zika and other Arboviruses by rapidly eliminating Aedes albopictus larvae from tires using a spray formulation of Bacillus thuringiensis israelensis. IOSR Journal of Dental and Medical Sciences 15: 104-107. DOI: 10.9790/0853-150907104107.

Kostyuchenko VA, Lim EXY, Zhang S, Fibriansah G, Ng TS, Ooi JSG, Shi J, Lok SM (2016) Structure of the thermally stable Zika virus. Nature, 2016; 553: 425-428.

Krauer F, Riesen M, Reveiz L, Oladapo OT, Martínez-Vega R, Porgo TV, Haefliger A, Broutet NJ, Low N, WHO Zika Causality Working Group (2017) Zika virus infection as a cause of congenital brain abnormalities and Guillain-Barré syndrome: systematic review. PLoS medicine 14: p.e1002203.

Krow-Lucal ER, Biggerstaff BJ, Staples JE (2017) Estimated Incubation Period for Zika Virus Disease. Emerging Infectious Diseases 23: 841.

Kühnel D, Müller S, Pichotta A, Radomski KU, Volk A, Schmidt T (2016) Inactivation of Zika virus by solvent/detergent treatment of human plasma and other plasma-derived products and pasteurization of human serum albumin. Transfusion 138:16212-16215.

Kumar M, Krause KK, Azouz F, Nakano E, Nerurkar VR (2017) A guinea pig model of Zika virus infection. Virology Journal 14: 75.

Lambe U, Prasad M, Brar B, Guray M, Ikbal, Ranjan K, Bansal N, Khurana SK, Manimegalai (2016) Nanodiagnostics: a new frontier for veterinary and medical sciences. Journal of Experimental Biology and Agricultural Sciences 4: 307-320.

Landry ML, St George K (2017) Laboratory Diagnosis of Zika Virus Infection. Archives of Pathology \& Laboratory Medicine 141:60-67.

Larocca RA, Abbink P, Peron JP, Zanotto PM, Iampietro MJ, BadamchiZadeh A, Boyd M, Ng'ang'a D, Kirilova M, Nityanandam R, Mercado NB, Li Z, Moseley ET, Bricault CA, Borducchi EN, Giglio PB, Jetton D, Neubauer G, Nkolola JP, Maxfield LF, De La Barrera RA, Jarman RG, Eckels KH, Michael NL, Thomas SJ, Barouch DH (2016) Vaccine protection against Zika virus from Brazil. Nature 536: 474-478.

Laurent-Rolle M, Morrison J, Rajsbaum R, Macleod JML, Pisanelli G, Pham A, Ayllon J, Miorin L, Martinez C, tenOever BR, García-Sastre A (2014) The interferon signaling antagonist function of yellow fever virus NS5 protein is activated by type I interferon. Cell Host Microbe $16: 314-327$.

Lazear HM (2017) What to expect when you're expecting Zika. Cell Host \& Microbe 21: 305-308.

DOI: http://dx.doi.org/10.1016/j.chom.2017.02.015.

Lazear HM, Govero J, Smith AM, Platt DJ, Fernandez E, Miner JJ, Diamond MS (2016) A mouse model of Zika virus pathogenesis. Cell Host 
\& Microbe 19: 720-730. doi: 10.1016/j.chom.2016.03.010.

Ledermann JP, Guillaumot L, Yug L, Saweyog SC, Tided M, Machieng P, Pretrick M, Marfel M, Griggs A, Bel M, Duffy MR, Hancock WT, HoChen T, Powers AM (2014) Aedes hensilli as a potential vector of Chikungunya and Zika viruses. PLOS Neglected Tropical Diseases 8:e3188.

Lee D, Shin Y, Chung S, Hwang KS, Yoon DS, Lee JH (2016) Simple and Highly Sensitive Molecular Diagnosis of Zika Virus by Lateral Flow Assays. Analytical Chemistry 88:12272-12278.

Lei J, Hansen G, Nitsche C, Klein CD, Zhang L, Hilgenfeld R (2016) Crystal structure of Zika virus NS2B-NS3 protease in complex with a boronate inhibitor. Science 353:503-5. doi: 10.1126/science.aag2419.

Leung GH, Baird RW, Druce J, Anstey NM (2015) Zika virus infection in Australia following a monkey bite in Indonesia. The Southeast Asian Journal of Tropical Medicine and Public Health 46: 460-464.

L'Huillier AG, Lombos E, Tang E, Perusini S, Eshaghi A, Nagra S, Frantz C, Olsha R, Kristjanson E, Dimitrova K, Safronetz D, Drebot M, Gubbay JB (2017) Evaluation of Altona Diagnostics RealStar Zika Virus RT-PCR Test Kit for Zika virus PCR testing. Journal of Clinical Microbiology 55: 1576-1584. doi: 10.1128/JCM.02153-16.

Li C, Deng YQ, Wang S, Ma F, Aliyari R, Huang XY, Zhang NN, Watanabe M, Dong HL, Liu P, Li XF, Ye Q, Tian M, Hong S, Fan J, Zhao H, Li L, Vishlaghi N, Buth JE, Au C, Liu Y, Lu N, Du P, Qin FX, Zhang B, Gong D, Dai X, Sun R, Novitch BG, Xu Z, Qin CF, Cheng G (2017) 25-Hydroxycholesterol Protects Host against Zika Virus Infection and Its Associated Microcephaly in a Mouse Model. Immunity 46 :446-456. doi: 10.1016/j.immuni.2017.02.012.

Li H, Saucedo-Cuevas L, Shresta S, Gleeson JG (2016) The Neurobiology of Zika Virus. Neuron 92: 949-958. DOI: https://doi.org/10.1016/j.neuron.2016.11.031.

Lim HJ, Nguyen TT, Kim NM, Park JS, Jang TS, Kim D (2017) Inhibitory effect of flavonoids against NS2B-NS3 protease of ZIKA virus and their structure activity relationship. Biotechnology Letters 39:415-421. doi: 10.1007/s10529-016-2261-6.

Lim L, Roy A, Song J (2016) Identification of a Zika NS2B-NS3 pro pocket susceptible to allosteric inhibition by small molecules including qucertin rich in edible plants. bioRxiv. doi: 10.1101/078543

Liu SQ, Li X, Deng CL, Yuan ZM, Zhang B (2017) Development and evaluation of one-step multiplex real-time RT-PCR assay for simultaneous detection of Zika virus and Chikungunya virus. Journal of Medical Virology doi: 10.1002/jmv.24970.

Londono-Renteria B, Troupin A, Colpitts TM (2016) Arbovirosis and potential transmission blocking vaccines. Parasites \& Vectors 9:516. doi: 10.1186/s13071-016-1802-0

Lu G, Bluemling GR, Collop P, Hager M, Kuiper D, Gurale BP, Painter GR, De La Rosa A, Kolykhalov AA (2017) Analysis of Ribonucleotide 5' Triphosphate analogs as potential inhibitors of Zika virus RNA-dependent RNA polymerase using non-radioactive polymerase assays. Antimicrobial Agents and Chemotherapy 61: pii: e01967-16. doi: 10.1128/AAC.01967-16.

Lucey DR, Gostin LO (2016) The emerging Zika pandemic: enhancing preparedness. The Journal of the American Medical Association 315:865866.

Mahalingam S, Teixeira MM, Halstead SB. (2017). Zika enhancement: a reality check. The Lancet Infectious Diseases 17 :686-688. doi: 10.1016/S1473-3099(17)30340-7.
Maharajan MK, Ranjan A, Chu JF, Foo WL, Chai ZX, Lau EY, Ye HM, Theam XJ, Lok YL (2016) Zika virus infection: current concerns and perspectives. Clinical Reviews in Allergy \& Immunology 51 :383-394.

Makhluf H, Shresta S (2018) Development of Zika virus vaccines. Vaccines 7: 1-9. doi:10.3390/vaccines6010007.

Malik YS, Sharma K, Jeena LM, Kumar N, Sircar S, Rajak KK, Dhama K (2013) Toll-like receptors: the innate immune receptors with ingenious anti-viral paradigm. South Asian Journal of Exprimental Biology 3: 207213.

Mansuy JM, Dutertre M, Mengelle C, Fourcade C, Marchou B, Delobel P, Izopet J, Martin-Blondel G (2016) Zika virus: high infectious viral load in semen, a new sexually transmitted pathogen? The Lancet Infectious Diseases 16:405-405. DOI: 10.1016/S1473-3099(16)00138-9.

Marano G, Pupella S, Vaglio S, Liumbruno GM, Grazzini G (2016) Zika virus and the never-ending story of emerging pathogens and transfusion medicine. Blood Transfusion 14: 95-100.

Marchette NJ, Garcia R, Rudnick A (1969) Isolation of Zika virus from Aedes aegypti mosquitoes in Malaysia. The American Journal of Tropical Medicine and Hygiene 18:411-415.

Marcondes CB, Ximenes MF (2016) Zika virus in Brazil and the danger of infestation by Aedes (Stegomyia) mosquitoes. Revista da Sociedade Brasileira de Medicina Tropical 49:4-10. doi:doi.org/10.1590/ 0037-86820220-2015.

Martines RB, Bhatnagar J, Keating MK, Silva-Flannery L, Muehlenbachs A, Gary J, Goldsmith C, Hale G, Ritter J, Rollin D, Shieh WJ, Luz KG, Ramos AM, Davi HP, Kleber de Oliveria W, Lanciotti R, Lambert A, Zaki S (2016a) Notes from the field: evidence of Zika virus infection in Brain and placental tissues from two congenitally infected newborns and two fetal losses - Brazil, 2015. Morbidity and Mortality Weekly Report (MMWR) 65:159-160.

Martins KAO, Dye JM, Bavari S (2016b) Considerations for the development of Zika virus vaccines. Vaccine 34:3711-2.

Medlock JM, Leach SA (2015) Effect of climate change on vector-borne disease risk in the UK. The Lancet Infectious Diseases 15:721-730.

Mehrjardi MZ, Poretti A, Huisman TA, Werner H, Keshavarz E, Júnior EA (2017) Neuroimaging findings of congenital Zika virus infection: a pictorial essay. Japanese Journal of Radiology 1-6.

Melo AS, Aguiar RS, Amorim MM, Arruda MB, Melo FO, Ribeiro ST, Batista AG, Ferreira T, Dos Santos MP, Sampaio VV, Moura SR, Rabello LP, Gonzaga CE, Malinger G, Ximenes R, de Oliveira-Szejnfeld PS, Tovar-Moll F, Chimelli L, Silveira PP, Delvechio R, Higa L, Campanati L, Nogueira RM, Filippis AM, Szejnfeld J, Voloch CM, Ferreira OC Jr, Brindeiro RM, Tanuri A (2016) Congenital Zika virus infection: Beyond neonatal microcephaly. JAMA Neurology 73: 1407-1416

Mesci P, Macia A, Moore SM, Shirayev SA, Pinto A, Huang CT, Tejwani L, Fernandes IR, Suarez NA, Kolar MJ, Montefusco S, Rosenberg SC, Herai RH, Cugola FR, Russo FB, Sheets N, Saghatelian A, Shresta S, Momper JD, Siqueira-Neto JL, Corbett KD, Beltrao-Braga PCB, Terskikh AB, Muotri AR (2018) Blocking Zika virus vertical transmission. Scientific Reports 8. Doi: 10.1038/s41598-018-19526-4.

Mirza MU, Rafique S, Ali A, Munir M, Ikram N, Manan A, Salo-Ahen OMH, Idrees M (2016) Towards peptide vaccines against Zika virus: Immunoinformatics combined with molecular dynamics simulations to predict antigenic epitopes of Zika viral proteins. Scientific Reports 6:37313. doi: $10.1038 /$ srep44633 
Mittal R, Fifer RC, Liu XZ (2017) A possible association between gearing loss and Zika virus infections. JAMA Otolaryngol Head \& Neck Surgery 144: 3-4. doi: 10.1001/jamaoto.2017.1798.

Mlakar J, Korva M, Tul N, Popovi CM, Polj_sak-Prijatelj M, Mraz J, Kolenc M, Resman Rus K, Vesnaver Vipotnik T, Fabjan Vodusek V, Vizjak A, Pižem J, Petrovec M, Avšič Županc T (2016) Zika virus associated with microcephaly. The New England Journal of Medicine 374:951-958.

Molko N, Simon O, Guyon D, Biron A, Dupont-Rouzeyrol M, Gourinat AC (2017) Zika virus infection and myasthenia gravis: report of 2 cases. Neurology 88:1097-1098.

Monath TP, Craven RB, Muth DJ, Trautt CJ, Calisher CH, Fitzgerald SA (1980) Limitations of the complement-fixation test for distinguishing naturally acquired from vaccineinduced yellow fever infection in flavivirus-hyperendemic areas. The American Journal of Tropical Medicine and Hygiene 29:624-634.

Monel B, Compton AA, Bruel T, Amraoui S, Burlaud-Gaillard J, Roy N, Guivel-Benhassine F, Porrot F, Génin P, Meertens L, Sinigaglia L, Jouvenet N, Weil R, Casartelli N, Demangel C, Simon-Lorière E, Moris A, Roingeard P, Amara A, Schwartz O (2017) Zika virus induces massive cytoplasmic vacuolization and paraptosis-like death in infected cells. The EMBO Journal e201695597. doi: 10.15252/embj.201695597.

Morrison C (2016) DNA vaccines against Zika virus speed into clinical trials. Nature Reviews Drug Discovery 15: 521-522.

Morrison J, Laurent-Rolle M, Maestre AM, Rajsbaum R, Pisanelli G, Simon V, Mulder LC, Fernandez-Sesma A, García-Sastre A (2013) Dengue virus co-opts UBR4 to degrade STAT2 and antagonize type I interferon signaling. PLoS Pathogens 9:e1003265.

Mounce BC, Cesaro T, Carrau L, Vallet T, Vignuzzi M (2017) Curcumin inhibits Zika and chikungunya virus infection by inhibiting cell binding. Antiviral Research 142: 148-157.

Mukherjee S, Era N (2016) Zika virus disease: Global concerns and making way through it. Community Acquired Infection $3: 31$.

Munjal A, Khandia R, Dhama K, Sachan S, Karthik K, Tiwari R, Malik YS, Kumar D, Singh RK, Iqbal HMN, Joshi SK (2017b) Advances in developing therapies to combat Zika virus: Current knowledge and future perspectives. Frontiers in Microbiology 8:1469. doi: 10.3389/fmicb.2017.01469.

Munjal A, Khandia R, Tiwari R, Chakraborty S, Karthik K, Dhama K (2017a) Advances in designing and developing vaccines against Zika virus. International Journal of Pharmacology 13:667-676.

Murugan K, Benelli G, Panneerselvam C, Subramaniam J, Jeyalalitha T, Dinesh D, Nicoletti M, Hwang JS, Suresh U, Madhiyazhagan P (2015b) Cymbopogon citratus-synthesized gold nanoparticles boost the predation efficiency of copepod Mesocyclops aspericornis against malaria and dengue mosquitoes. Experimental Parasitology 153:129-138. doi: 10.1016/j.exppara.2015.03.017.

Murugan K, Priyanka V, Dinesh D, Madhiyazhagan P, Panneerselvam C, Subramaniam J, Suresh U, Chandramohan B, Roni M, Nicoletti M, Alarfaj AA, Higuchi A, Munusamy MA, Khater HF, Messing RH, Benelli G (2015b) Predation by Asian bullfrog tadpoles, Hoplobatrachus tigerinus, against the dengue vector, Aedes aegypti, in an aquatic environment treated with mosquitocidal nanoparticles. Parasitology Research 114: 36013610. doi: 10.1007/s00436-015-4582-0

Musso D, Aubry M, Broult J, Stassinopoulos A, Green J (2017) Zika virus: new emergencies, potential for severe complications, and prevention of transfusion-transmitted Zika fever in the context of co-circulation of arboviruses. Blood Transfusion 15:272.

Musso D, Gubler DJ (2016) Zika Virus. Clinical Microbiology Reviews 29: 487-524.

Musso D, Nhan T, Robin E, Roche C, Bierlaire D, Zisou K, Shan Yan A, Cao-Lormeau VM, Broult J (2014) Potential for Zika virus transmission through blood transfusion demonstrated during an outbreak in French Polynesia, November 2013 to February 2014. Revista Brasileira de Hematologia e Hemoterapia 19: pii: 20761.

Musso D, Roche C, Robin E, Nhan T, Teissier A, Cao-Lormeau VM (2015) Potential sexual transmission of Zika virus. Emerging Infectious Diseases journal 21: 359-361.

Nandi S, Kwong AT, Holtz BR, Erwin RL, Marcel S, McDonald KA (2016) Techno-economic analysis of a transient plant-based platform for monoclonal antibody production. mAbs 8: 1456-1466.

Nayak S, Lei J, Pekosz A, Klein S, Burd I (2016) Pathogenesis and Molecular Mechanisms of Zika Virus. Seminars in Reproductive Medicine 34: $266-272$.

Neelakanta G, Sultana H (2015) Transmission-blocking vaccines: focus on anti-vector vaccines against tick-borne diseases. Archivum Immunolgiae et Therapiae Experimentalis 63: 169-179. doi: 10.1007/s00005-014-0324-8

Nereida V (2015) Zika virus: another emerging arbovirus in Venezuela? Investigacion Clinica 56:241-242.

Ng WC, Soto-Acosta R, Bradrick SS, Garcia-Blanco MA, Ooi EE (2017) The 5'and 3' Untranslated Regions of the Flaviviral Genome. Viruses 9:137; doi: 10.3390/v9060137.

Nguyen SM, Antony KM, Dudley DM, Golos TG (2017) Highly efficient maternal-fetal Zika virus transmission in pregnant rhesus macaques. PLOS Pathogens 13:e1006378. doi: 10.1371/journal.ppat.1006378.

Nguyen TH, Nguyen HL, Nguyen TY, Vu SN, Tran ND, Le TN, Vien QM, Bui TC, Le HT, Kutcher S, Hurst TP, Duong TT, Jeffery JA, Darbro JM, Kay BH, Iturbe-Ormaetxe I, Popovici J, Montgomery BL, Turley AP, Zigterman F, Cook H, Cook PE, Johnson PH, Ryan PA, Paton CJ, Ritchie SA, Simmons CP, O'Neill SL, Hoffmann AA (2015) Field evaluation of the establishment potential of wmelPop Wolbachia in Australia and Vietnam for dengue control. Parasites \& Vectors 8:563. doi: 10.1186/s13071-015-1174-x.

Nowakowski TJ, Pollen AA, Di Lullo E, Sandoval-Espinos C, Bershteyn M, Kriegstein AR (2016) Expression analysis highlights AXL as a candidate Zika virus entry receptor in neural stem cells. Cell Stem Cell 18:591-596. doi: 10.1016/j.stem.2016.03.012.

Olagnier D, Amatore D, Castiello L, Ferrari M, Palermo E, Diamond MS, Palamara AT, Hiscott J (2016) Dengue virus immunopathogenesis: lessons applicable to the emergence of Zika virus. Journal of Molecular Biology 428 :3429-3448. doi: 10.1016/j.jmb.2016.04.024.

Ornelas AM, Pezzuto P, Silveira PP, Melo FO, Ferreira TA, OliveiraSzejnfeld PS, Leal JI, Amorim MM, Hamilton S, Rawlinson WD, Cardoso CC, Nixon DF, Tanuri A, Melo AS, Aguiar RS (2017) Immune activation in amniotic fluid from Zika virus-associated microcephaly. Annals of Neurology 81:152-156. doi: 10.1002/ana.24839.

Oster AM, Brooks JT, Stryker JE, Kachur RE, Mead P, Pesik NT, Petersen LR (2016) Interim Guidelines for Prevention of Sexual Transmission of Zika Virus - United States 2016. Morbidity and Mortality Weekly Report (MMWR) 65:120-121. doi:10.15585/mmwr.mm6505e1. 
Osuna CE, Lim SY, Deleage C, Griffin BD, Stein D, Schroeder LT, Omange R, Best K, Luo M, Hraber PT, Andersen-Elyard H (2016) Zika viral dynamics and shedding in rhesus and cynomolgus macaques. Nature Medicine 22:1448-1455.

Pan American Health Organization/World Health Organization (PAHO/ WHO) (2016) Regional Zika Epidemiological Update (Americas): 2 June 2016.

http://www.paho.org/hq/index.php?option=com_content\&view=article\&id $=11599 \&$ Itemid $=41691$.

Pantoja P, Pérez-Guzmán EX, Rodríguez IV, White LJ, González O, Serrano C, Giavedoni L, Hodara V, Cruz L, Arana T, Martínez MI, Hassert MA, Brien JD, Pinto AK, de Silva A, Sariol CA (2017) Zika virus pathogenesis in rhesus macaques is unaffected by pre-existing immunity to dengue virus. Nature Communications 8:15674 doi: $10.1038 /$ ncomms 15674

Pardee K, Green AA, Takahashi MK, Braff D, Lambert G, Lee JW, Ferrante T, Ma D, Donghia N, Fan M, Daringer NM, Bosch I, Dudley DM, O'Connor DH, Gehrke L, Collins JJ (2016) Rapid, Low Cost Detection of Zika Virus Using Programmable Biomolecular Compone nts. Cell 165:1255-66.

Pardi N, Hogan MJ, Pelc RS, Muramatsu H, Andersen H, DeMaso CR, Dowd KA, Sutherland LL, Scearce RM, Parks R, Wagner W, Granados A, Greenhouse J, Walker M, Willis E, Yu JS, McGee CE, Sempowski GD, Mui BL, Tam YK, Huang YJ, Vanlandingham D, Holmes VM, Balachandran H, Sahu S, Lifton M, Higgs S, Hensley SE, Madden TD, Hope MJ, Karikó K, Santra S, Graham BS, Lewis MG, Pierson TC, Haynes BF, Weissman D (2017) Zika virus protection by a single low-dose nucleoside-modified mRNA vaccination. Nature 543: 248-251. doi: 10.1038/nature21428. Epub 2017 Feb 2.

Parham PE, Waldock J, Christophides GK, Michael E (2015) Climate change and vector-borne diseases of humans. Philosophical Transactions of the Royal Society of London. Series B 370 : pii: 20140377.

Parra B, Lizarazo J, Jiménez-Arango JA, Zea-Vera AF, GonzálezManrique G, Vargas J, Angarita JA, Zuñiga G, Lopez-Gonzalez R, Beltran CL, Rizcala KH, Morales MT, Pacheco O, Ospina ML, Kumar A, Cornblath DR, Muñoz LS, Osorio L, Barreras P, Pardo CA (2016) Guillain-Barré syndrome associated with Zika virus infection in Colombia. The New Engand Journal of Medicine 375:1513-1523. DOI: 10.1056/NEJMoa1605564.

Pascoalino BS, Courtemanche G, Cordeiro MT, Gil LH, Freitas-Junior L (2016) Zika antiviral chemotherapy: identification of drugs and promising starting points for drug discovery from an FDA-approved library. F1000Research 2016; 5:2523.

Passi D, Sharma S, Dutta SR, Ahmed M (2017) Zika Virus Diseases - The New Face of an Ancient Enemy as Global Public Health Emergency (2016): Brief Review and Recent Updates. International Journal of Preventive Medicine 8:6.

Pastula DM, Smith DE, Beckham JD, Tyler KL (2016) Four emerging arboviral diseases in North America: Jamestown Canyon, Powassan, chikungunya, and Zika virus diseases. Journal of NeuroVirology 22:25760. doi:10.1007/s13365-016-0428-5.

Paul LM, Carlin ER, Jenkins MM, Tan AL, Barcellona CM, Nicholson CO, Michael SF, Isern S (2016) Dengue virus antibodies enhance Zika virus infection. Clinical \& Translational Immunology 5: e117.

Paz-Bailey G, Rosenberg ES, Doyle K, Munoz-Jordan J, Santiago GA, Klein L, Perez-Padilla J, Medina FA, Waterman SH, Gubern CG, Alvarado LI, Sharp TM (2017) Persistence of Zika Virus in Body
Fluids - Preliminary Report. The New England Journal of Medicine; doi: 10.1056/NEJMoa1613108. [2017, Feb 14, Epub ahead of print].

Pegg AE (2008). Spermidine/spermine-N(1)-acetyltransferase: a key metabolic regulator. American Journal of Physiology, Endocrinology and Metabolism 294:E995-E1010.

Perreira JM, Chin CR, Feeley EM, Brass AL (2013) IFITMs restrict the replication of multiple pathogenic viruses. Journal of Molecular Biology 425:4937-4955.

Petersen E, Wilson ME, Touch S, McCloskey B, Mwaba P, Bates M, Dar O, Mattes F, Kidd M, Ippolito G, Azhar EI, Zumla A (2016b) Rapid spread of Zika virus in the Americas - implications for public health preparedness for mass gatherings at the 2016 Brazil Olympic Games. International Journal of Infectious Diseases 44:11-15. doi: 10.1016/j.ijid.2016.02.001.

Petersen LR, Jamieson DJ, Powers AM, Honein MA (2016a) Zika virus. The New England Journal of Medicine 374:1552-1563.

Pierson TC, Graham BS (2016) Zika Virus: Immunity and vaccine development. Cell 167:625-631.

Plourde AR, Bloch EM (2016) A literature review of Zika virus. Emerging Infectious Diseases 22: 1185-1192. doi: 10.3201/eid2207.151990.

Poland GA, Kennedy RB, McKinney BA, Ovsyannikova IG, Lambert ND, Jacobson RM, Oberg AL (2013) Vaccinomics, adversomics, and the immune response network theory: individualized vaccinology in the 21 st century. In Seminars in immunology. Academic Press 25: 89-103.

Poland GA, Kennedy RB, McKinney BA, Ovsyannikova IG, Palacois R, Ho PL, Kalil J (2018) Development of vaccines against Zika virus. The Lancet Infectious Diseases (In Press). https://doi.org/10.1016/S14733099(18)30063-X.

Poland GA, Ovsyannikova IG, Kennedy RB, Haralambieva IH, Jacobson RM (2011) Vaccinomics and a new paradigm for the development of preventive vaccines against viral infections. Omics 15: 625-636.

Prasad M, Lambe UP, Brar B, Shah I, Manimegalai J, Ranjan K, Rao R, Kumar S, Mahant S, Khurana SK, Iqbal HMN, Dhama, K, Misri J, Prasad $G$ (2018). Nanotherapeutics: An insight into healthcare and multidimensional applications in medical sector of the modern world. Biomedicine \& Pharmacotherapy 97: 1521-1537.

Priyamvada L, Quicke KM, Hudson WH, Onlamoon N, Sewatanon J, Edupuganti S, Pattanapanyasat K, Chokephaibulkit K, Mulligan MJ, Wilson PC, Ahmed R, Suthar MS, Wrammert J (2016) Human antibody responses after dengue virus infection are highly cross-reactive to Zika virus. Proceedings of the National Academy of Sciences of the United State of America $113: 7852-7857$.

Priye A, Bird SW, Light YK, Ball CS, Negrete OA, Meagher RJ (2017) A smart phone-based diagnostic platform for rapid detection of Zika, chikungunya, and dengue viruses. Scientific Reports - Nature 7:44778.

Pyke AT, Daly MT, Cameron JN, Moore PR, Taylor CT, Hewitson GR, Humphreys JL, Gair R (2014) Imported zika virus infection from the Cook Islands into Australia. PLOS Currents $6 . \quad$ pii: ecurrents.outbreaks.4635a54dbffba2156fb2fd76dc49f65e.

Rabe IB, Staples JE, Villanueva J, Hummel KB, Johnson JA, Rose L, MTS, Hills S, Wasley A, Fischer M, Powers AM (2016) Interim guidance for interpretation of Zika virus antibody test results. Morbidity and Mortality Weekly Report (MMWR)65:543-546. doi:10.15585/mmwr.mm6521e1

Rajeswary M, Govindarajan M, Alharbi NS, Kadaikunnan S, Khaled JM, Benelli G (2017) Zingiber cernuum (Zingiberaceae) essential oil as 
effective larvicide and oviposition deterrent on six mosquito vectors, with little non-target toxicity on four aquatic mosquito predators. Environmental Science and Pollution Research, 1-10. doi: 10.1007/s11356-017-9093-3.

Ramharack P, Soliman ME (2017) Zika virus NS5 protein potential inhibitors: an enhanced in silico approach in drug discovery. Journal of Biomolecular Structure and Dynamics 1-16. doi: 10.1080/07391102.2017.1313175.

Rather IA, Kumar S, Bajpai VK, Lim J, Park YH (2017) Prevention and control strategies to counter Zika epidemic. Frontiers in Microbiology, Pp. 1-8. doi: 10.3389/fmicb.2017.00305.

Rausch K, Hackett BA, Weinbren NL, Reeder SM, Sadovsky Y, Hunter CA, Schultz DC, Coyne CB, Cherry S (2017) Screening bioactives reveals nanchangmycin as a broad spectrum antiviral active against Zika virus. Cell reports 18: 804-815.

Reegan AD, Gandhi MR, Paulraj MG, Ignacimuthu S (2015) Ovicidal and oviposition deterrent activities of medicinal plant extracts against Aedes aegypti L. and Culex quinquefasciatus say mosquitoes (Diptera: Culicidae). Osong Public Health Res Perspect 6: 64-69.

Ren P, Ortiz DA, Terzian AC, Colombo TE, Nogueira ML, Vasilakis N, Loeffelholz MJ (2017) Evaluation of Aptima Zika Virus Assay. Journal of Clinical Microbiology 55: 2198-2203. doi: 10.1128/JCM.00603-17

Retallack H, Di Lullo E, Arias C, Knopp KA, Laurie MT, SandovalEspinosa C, Mancia Leon WR, Krencik R, Ullian EM, Spatazza J, Pollen AA, Mandel-Brehm C, Nowakowski TJ, Kriegstein AR, DeRisi JL (2016) Zika virus cell tropism in the developing human brain and inhibition by azithromycin. Proceedings of the National Academy of Sciences of the United States of America 113 :14408-14413. doi: $10.1073 /$ pnas. 1618029113 .

Reveiz L, Haby MM, Martínez-Vega R, Pinzón-Flores CE, Elias V, Smith E, Pinart M, Broutet N, Becerra-Posada F, Aldighieri S, Van Kerkhove MD (2017) Risk of bias and confounding of observational studies of Zika virus infection: A scoping review of research protocols. PloS One 12: p.e0180220.

Reznik SE, Ashby JC (2016) Sofosbuvir: an anti-viral drug with potential efficacy against Zika infection. International Journal of Infectious Diseases pii: S1201-9712(16)31654-X. doi: 10.1016/j.ijid.2016.12.011.

Richner JM, Himansu S, Dowd KA, Butler SL, Salazar V, Fox JM, Julander JG, Tang WW, Shresta S, Pierson TC, Ciaramella G, Diamond MS (2017) Modified mRNA Vaccines Protect against Zika Virus Infection. Cell 168:1114-1125. DOI: http://dx.doi.org/10.1016/j.cell.2017.02.017.

Roa M (2016) Zika virus outbreak: reproductive health and rights in Latin America. Lancet 387:843.

Robbiani DF, Bozzacco L, Keeffe JR, Khouri R, Olsen PC, Gazumyan A, Schaefer-Babajew D, Avila-Rios S, Nogueira L, Patel R, Azzopardi SA, Uhl LFK, Saeed M, Sevilla-Reyes EE, Agudelo M, Yao KH, Golijanin J, Gristick HB, Lee YE, Hurley A, Caskey M, Pai J, Oliveira T, Wunder EA Jr, Sacramento G, Nery N Jr, Orge C, Costa F, Reis MG, Thomas NM, Eisenreich T, Weinberger DM, de Almeida ARP, West AP Jr, Rice CM, Bjorkman PJ, Reyes-Teran G, Ko AI, MacDonald MR, Nussenzweig MC (2017) Recurrent potent human neutralizing antibodies to Zika virus in Brazil and Mexico. Cell 169 : 597-609. DOI: http://dx.doi.org/10.1016/j.cell.2017.04.024

Rodriguez-Morales AJ (2015) Zika: the new arbovirus threat for Latin America. The Journal of Infection in Developing Countries 9:684-685.

Rodriguez-Morales AJ (2016) Zika and microcephaly in Latin America: An emerging threat for pregnant travelers? Travel Medicine and Infectious Disease 14:5-6.
Rossi P, Ricci I, Cappelli A, Damiani C, Ulissi U, Mancini MV, Valzano M, Capone A, Epis S, Crotti E, Chouaia B, Scuppa P, Joshi D, Xi Z, Mandrioli M, Sacchi L, O’Neill SL, Favia G (2015) Mutual exclusion of Asaia and Wolbachia in the reproductive organs of mosquito vectors. Parasites \& Vectors 8:278. doi: 10.1186/s13071-015-0888-0.

Roy A, Lim L, Song J (2016) Identification of quercetin from fruits to immediately fight Zika. BioRxiv 074559. doi: https://doi.org/10.1101/074559.

Sacramento CQ, de Melo GR, de Freitas CS, Rocha N, Hoelz LVB, Miranda M, Fintelman-Rodrigues N, Marttorelli A, Ferreira AC, BarbosaLima G, Abrantes JL, Vieira YR. Bastos MM, de Mello Volotão E, Nunes EP, Tschoeke DA, Leomil L, Loiola EC, Trindade P, Rehen SK, Bozza FA, Bozza PT, Boechat N, Thompson FL, de Filippis AM, Brüning K, Souza TM (2017) The clinically approved antiviral drug sofosbuvir inhibits Zika virus replication. Scientific Reports (Nature) 7: 40920.

Sahoo M, Jena L, Daf S, Kumar S (2016) Virtual screening for potential inhibitors of ns3 protein of Zika virus. Genomics and Informatics 14:104111.

Samarasekera U, Triunfol M (2016) Concern over Zika virus grips the world. Lancet 387:521-524.

Santa Maria F, Laughhunn A, Lanteri MC, Aubry M, Musso D, Stassinopoulos A (2017) Inactivation of Zika virus in platelet components using amotosalen and ultraviolet A illumination. Transfusion 57: 20162025. doi: 10.1111/trf.14161.

Sapparapu G, Fernandez E, Kose N, Cao B, Fox JM, Bombardi RG, Zhao H, Nelson CA, Bryan AL, Barnes T, Davidson E, Mysorekar IU, Fremont DH, Doranz BJ, Diamond MS, Crowe JE (2016) Neutralizing human antibodies prevent Zika virus replication and fetal disease in mice. Nature 540:443-447. doi: 10.1038/nature20564.

Sarwar M (2015) Control of dengue carrier Aedes mosquitoes (Diptera: Culicidae) larvae by larvivorous fishes and putting it into practice within water bodies. International Journal of Preventive Medicine 1: 232-237.

Savidis G, Perreira JM, Portmann JM, Meraner P, Guo Z, Green S, Brass AL (2016) The IFITMs inhibit Zika virus replication. Cell Reports 15 : 2323-30. doi: 10.1016/j.celrep.2016.05.074.

Schuler-Faccini L, Ribeiro EM, Feitosa IM, Horovitz DD, Cavalcanti DP, Pessoa A, Doriqui MJ, Neri JI, Neto JM, Wanderley HY, Cernach M, ElHusny AS, Pone MV, Serao CL, Sanseverino MT; Brazilian Medical Genetics Society-Zika Embryopathy Task Force (2016) Possible association between Zika virus infection and microcephaly - Brazil, 2015. Morbidity and Mortality Weekly Report (MMWR) 65:59-62.

Setoh YX, Prow NA, Peng N, Hugo LE, Devine G, Hazlewood JE, Suhrbier A, Khromykh AA (2017) De novo generation and characterization of new Zika virus isolate using sequence data from a microcephaly case. mSphere 2: pii:e00190-17.

Shadgan B, Pakravan A, Zaeimkohan H, Shahpar FM, Khodaee M (2016) Zika and Rio Olympic Games. Current Sports Medicine Reports 15:298-300.

Shan C, Xie X, Barrett ADT, Garcia-Blanco MA, Tesh RB, da CostaVasconcelos PF, Vasilakis N, Weaver SC, Shi PY (2016) Zika virus: diagnosis, therapeutics, and vaccine, ACS Infectious Diseases $2: 170-172$.

Shan C, Muruato AE, Jagger BW, Richner J, Nunes BTD, Medeiros DBA, Xie X, Nunes JGC, Morabito KM, Kong WP, Pierson TC, Barrett AD, Weaver SC, Rossi SL, Vasconcelos PFC, Graham BS, Diamond MS, Shi PY (2017) A single-dose live-attenuated vaccine prevents Zika virus pregnancy transmission and testis damage. Nature Communications $8: 676$. 
Shankar A, Patil AA, Skariyachan S (2017) Recent perspectives on genome, transmission, clinical manifestation, diagnosis, therapeutic strategies, vaccine developments and challenges of Zika virus research. Frontiers in Microbiology. doi: 10.3389/fmicb.2017.01761 (In Press).

Sharma A, Lal SK (2017) Zika virus: Transmission, detection, control, and prevention. Frontiers in Microbiology 8:110.

Shoaib M, Faraz A, Ahmed SA (2016) Another vector borne challenge to combat-zika virus outbreaks. Journal of Ayub Medical College Abbottabad 28: 210-211.

Shuaib W, Stanazai H, Abazid AG, Mattar AA (2016) Re-Emergence of Zika Virus: A review on pathogenesis, clinical manifestations, diagnosis, treatment, and prevention. American Journal of Medicine 129:879.e7879.e12. doi: 10.1016/j.amjmed.2016.02.027.

Singh RK, Dhama K, Malik YS, Ramakrishnan MA, Karthik K, Tiwari R, Saurabh S, Sachan S, Joshi SK (2016) Zika virus - emergence, evolution, pathology, diagnosis, and control: current global scenario and future perspectives - a comprehensive review. The Veterinary quarterly 36:150175. doi: 10.1080/01652176.2016.1188333.

Singh RK, Dhama K, Malik YS, Ramakrishnan MA, Karthik K, Tiwari R, Munjal A, Saminathan M, Sachan S, Desingu PA, Kattoor JJ, Iqbal HM, Joshi SK (2017) Ebola virus - epidemiology, diagnosis and control: threat to humans, lessons learnt and preparedness plans - An update on its 40 year's journey. The Veterinary Quarterly 37:98-135.

Singh RK, Badasara SK, Dhama K, Malik YPS (2015) Progress and prospects in vaccine research. Chapter in National Workshop on "Current Trends and Future Research Challenges in Vaccines and Adjuvants". Organized at ICAR Indian Veterinary Research Institute, Izatnagar, Bareilly, Uttar Pradesh, India during 19-20 November 2015 Pp: 1-19.

Singh RK, Dhama K, Karthik K, Tiwari R, Khandia R, Munjal A, Iqbal HMN, Malik YS, Bueno-Marí R (2018a) Advances in diagnosis, surveillance, and monitoring of Zika virus: An update. Frontiers in Microbiology 8:2677. doi: 10.3389/fmicb.2017.02677

Singh RK, Dhama K, Khandia R, Munjal A, Karthik K, Tiwari R, Chakraborty S, Malik YS, Bueno-Marí R (2018b) Prevention and control strategies to counter Zika virus, a special focus on intervention approaches against vector mosquitoes - Current updates. Frontiers in Microbiology doi: 10.3389/fmicb.2018.00087

Sirohi D, Chen Z, Sun L, Klose T, Pierson TC, Rossmann MG, Kuhn RJ (2016) The $3.8 \AA$ resolution cryo-EM structure of Zika virus. Science 352:467-470.

Sousa AQ, Cavalcante DIM, Franco LM, Araújo FMC, Sousa ET, Valença-Junior JT, Rolim DB, Melo MEL, Sindeaux PDT, Araújo MTF, Pearson RD, Wilson ME, Pompeu MML (2017) Postmortem Findings for 7 Neonates with Congenital Zika Virus Infection. Emerging Infectious Diseases journal 23:1164-1167. doi: 10.3201/eid2307.162019.

Specter M (2012) The osquito Solution. The New Yorker http://www.newyorker.com/magazine/2012/07/09/the-mosquito-solution.

Spencer JL, Lahon A, Tran LL, Arya RP, Kneubehl AR, Vogt MB, Xavier D, Rowley DR, Kimata JT, Rico-Hesse RR (2017) Replication of Zika virus in human prostate cells: a potential source of sexually transmitted virus. Journal of Infectious Diseases doi: 10.1093/infdis/jix436.

St George K, Sohi IS, Dufort EM, Dean AB, White JL, Limberger R, Sommer JN, Ostrowski S, Wong SJ, Backenson PB, Kuhles D, Blog D, Taylor J, Hutton B, Zucker HA (2017) Zika virus testing considerations: Lessons learned from the first 80 real-time reverse transcription-PCRpositive cases diagnosed in New York State. Journal of Clinical Microbiology 55:535-544.
Staples JE, Dziuban EJ, Fischer M, Cragan JD, Rasmussen SA, Cannon MJ, Frey MT, Renquist CM, Lanciotti RS, Muñoz JL, Powers AM, Honein MA, Moore CA (2016) Interim guidelines for the evaluation and testing of infants with possible congenital Zika virus infection: United States, 2016. Morbidity and Mortality Weekly Report (MMWR) 65:63-67.

Steinhagen K, Probst C, Radzimski C, Schmidt-Chanasit J, Emmerich P, van Esbroeck M, Schinkel J, Grobusch MP, Goorhuis A, Warnecke JM, Lattwein E, Komorowski L, Deerberg A, Saschenbrecker S, Stöcker W, Schlumberger W (2016) Serodiagnosis of Zika virus (ZIKV) infections by a novel NS1-based ELISA devoid of cross-reactivity with dengue virus antibodies: a multicohort study of assay performance, 2015 to 2016. Euro Surveill 21: pii: 30426

Stephen P, Baz M, Boivin G, Lin SX (2016) Structural insight into NS5 of Zika virus leading to the discovery of MTase inhibitors. Journal of the American Chemical Society 138:16212-16215.

Streblowb DN, Haddada EK, Trautmanna L, Rossa T, Linc R, Hiscotta J (2015) Sequence-Specific Modifications Enhance the Broad-Spectrum Antiviral Response Activated by RIG-I Agonists. Journal of Virology 89:8011-8025.

Sumathy K, Kulkarni B, Gondu RK, Ponnuru SK, Bonguram N, Eligeti R, Gadiyaram S, Praturi U, Chougule B, Karunakaran L, Ella KM (2017) Protective efficacy of Zika vaccine in AG129 mouse model. Scientific Reports 7- 46375

Sumita LM, Rodrigues JP, Ferreira NE, Felix AC, Souza NC, Machado CM, Júnior HF (2016) Detection of human anti-zika virus IgG by Elisa using an antigen from in vitro infected Vero cells: preliminary results. Revista do Instituto de Medicina Tropical de São Paulo 58:89. doi: 10.1590/S1678-9946201658089.

Summers DJ, Acosta RW, Acosta AM (2015) Zika virus in an American recreational traveler. Journal of Travel Medicine 22:338-340.

Surasombatpattana P, Hamel R, Patramool S, Luplertlop N, Thomas F, Despres P, Briant L, Yssel H, Missé D (2011) Dengue virus replication in infected human keratinocytes leads to activation of antiviral innate immune responses. Infection, Genetics and Evolution 11:1664-1673. 10.1016/j.meegid.2011.06.009.

Suy A, Sulleiro E, Rodó C, Vázquez É, Bocanegra C, Molina I, Esperalba J, Sánchez-Seco MP, Boix H, Pumarola T, Carreras E (2016) Prolonged Zika Virus Viremia during Pregnancy. The New England Journal of Medicine 375: 2611-2613. DOI: 10.1056/NEJMc1607580.

Suzuki Y, Chin WX, Han Q, Ichiyama K, Lee CH, Eyo ZW, Ebina H, Takahashi H, Takahashi C, Tan BH, Hishiki T, Ohba K, Matsuyama T, Koyanagi Y, Tan YJ, Sawasaki T, Chu JJ, Vasudevan SG, Sano K, Yamamoto N (2016) Characterization of RyDEN (C19orf66) as an Interferon-Stimulated Cellular Inhibitor against Dengue Virus Replication. PLOS Pathogens 12:e1005357. doi: 10.1371/journal.ppat.1005357.

Sze A, Olagnier D, Hadj SB, Han X, Tian XH, Xu HT, Yang L, Shi Q, Wang P, Wainberg MA, Wu JH, Lin R (2017) Sophoraflavenone G restricts Dengue and Zika virus infection via RNA polymerase interference. Viruses 9. pii: E287.

Tan CW, Sam IC, Chong WL, Lee VS, Chan YF (2017) Polysulfonate suramin inhibits Zika virus infection. Antiviral Research 143:186-194. doi: 10.1016/j.antiviral.2017.04.017.

Tang H, Hammack C, Ogden SC, Wen Z, Qian X, Li Y, Yao B, Shin J, Zhang F, Lee EM, Christian KM, Didier RA, Jin P, Song H, Ming GL (2016) Zika virus infects human cortical neural progenitors and attenuates their growth. Cell Stem Cell 18:587-590. 
Tappe D, Rissland J, Gabriel M, Emmerich P, Gunther S, Held G, Smola S, Schmidt-Chanasit J (2014) First case of laboratory-confirmed ZIKA infection imported into Europe, November 2013. Euro Surveillance 19:20685. doi: 10.2807/1560-7917. es2014.19.4.20685.

Tebas P, Roberts CC, Muthumani K, Reuschel EL, Kudchodkar SB, Zaidi FI, White S, Khan AS, Racine T, Choi H, Boyer J, Park YK, Trottier S, Remigio C, Krieger D, Spruill SE, Bagarazzi M, Kobinger GP, Weiner DB, Maslow JN (2017) Safety and immunogenicity of an anti-Zika virus DNA vaccine - Preliminary report. New England Journal of Medicine doi: 10.1056/NEJMoa1708120.

Teruya J, Versalovic J (2017) From Z to A: Putting Zika virus in perspective. The Journal of Thoracic and Cardiovascular Surgery. 154:303-304. doi: http://dx.doi.org/10.1016/j.jtcvs.2016.11.074.

Tiago PV, de Oliveira NT, de Luna EÁ, Lima A (2014) Biological insect control using Metarhizium anisopliae: morphological, molecular, and ecological aspects. Ciência Rural 44:645-651. doi: 10.1590/S010384782014000400012

Tian H, Ji X, Yang X, Xie W, Yang K, Chen C, Wu C, Chi H, Mu Z, Wang Z, Yang H (2016) The crystal structure of Zika virus helicase: basis for antiviral drug design. Protein \& Cell 7: 450-454. doi: 10.1007/s13238016-0275-4.

Tiwari R, Latheef SK, Ahmed I, Iqbal HMN, Bule MH, Dhama K, Samad HA, Karthik K, Alagawany M, El-Hack MEA, Yatoo MI, Farag MR (2018) Herbal immunomodulators, a remedial panacea for the designing and developing effective drugs and medicines: Current scenario and future prospects. Current Drug Metabolism 2018 Jan 29. doi: 10.2174/1389200219666180129125436. [Epub ahead of print]

Tognarelli J, Ulloa S, Villagra E, Lagos J, Aguayo C, Fasce R, Parra B, Mora J, Becerra N, Lagos N, Vera L, Olivares B, Vilches M, Fernández J (2015) A report on the outbreak of Zika virus on Easter Island, South Pacific, 2014. Archives of Virology 161:665-668. doi: 10.1007/s00705015-2695-5.

Torjesen I (2016) Zika virus outbreaks prompt warnings to pregnant women. BMJ 352:i500.

Tuse D, Tu T, McDonald K (2014) Manufacturing economics of plantmade biologics: case studies in therapeutic and industrial enzymes. BioMed Research International 2014: 10.

Uncini A, Shahrizaila N, Kuwabara S (2017) Zika virus infection and Guillain-Barré syndrome: a review focused on clinical and electrophysiological subtypes. Journal of Neurology, Neurosurgery, \& Psychiatry 88: 266-271.

Uraki R, Hwang J, Jurado KA, Householder S, Yockey LJ, Hastings AK, Homer RJ, Iwasaki A, Fikrig E (2017) Zika virus causes testicular atrophy. Science Advances 3: e1602899. doi: 10.1126/sciadv.1602899. eCollection 2017 Feb.

van den Berg H, Zaim M, Yadav RS, Soares A, Ameneshewa B, Mnzava A, Hii J, Dash AP, Ejov M (2012) Global trends in the use of insecticides to control vector-borne diseases. Environmental Health Perspectives 120:577-582.

van den Hurk AF, Hall-Mendelin S, Jansen CC, Higgs S (2017) Zika virus and Culex quinquefasciatus mosquitoes: a tenuous link. Lancet Infectious Diseases 17:1014-1016.

Van Kerkhove MD, Reveiz L, Souza JP, Jaenisch T, Carson G, Broutet N, Working Group on ZIKV Harmonized Research (2016) Harmonisation of Zika virus research protocols to address key public health concerns. The Lancet Global Health 4: 911-912. DOI: http://dx.doi.org/10.1016/S2214109X(16)30255-8.
Varghese FS, Rausalu K, Hakanen M, Saul S, Kümmerer BM, Susi P, Merits A, Ahola T (2017) Obatoclax inhibits alphavirus membrane fusion by neutralizing the acidic environment of endocytic compartments. Antimicrobial Agents Chemotherapy 61: e02227-16. doi: 10.1128/AAC.02227-16.

Veljkovic V, Paessler S (2016) Possible repurposing of seasonal influenza vaccine for prevention of Zika virus infection. F1000 Research 5:190.

Ventura LO, Ventura CV, Lawrence L, van der Linden V, van der Linden A, Gois AL, Cavalcanti MM, Barros EA, Dias NC, Berrocal AM, Miller MT (2017) Visual impairment in children with congenital Zika syndrome. Journal of American Association for Pediatric Ophthalmology and Strabismus. pii: S1091-8531(17)30311-7. doi: 10.1016/j.jaapos.2017.04.003.

Vest KG (2017) Zika Virus Update: More on an Emerging Arboviral Disease in the Western Hemisphere. Disaster Medicine and Public Health Preparedness 11:163-167.

von Seidlein L, Kekulé AS, Strickman D (2017) Novel vector control approaches: The future for prevention of Zika virus transmission? PLOS Medicine14:e1002219.

Vythilingam I, Sam JIC, Chan YF, Khaw LT, Wan Sulaiman WY (2016) New paradigms for virus detection, surveillance and control of Zika virus vectors in the settings of southeast asia. Frontiers in Microbiology 7: 1452. doi: $10.3389 /$ fmicb.2016.01452.

Waggoner JJ, Pinsky BA (2016) Zika virus: diagnostics for an emerging pandemic threat. Journal of Clinical Microbiology 54:860-867.

Waldorf KMA, Stencel-Baerenwald JE, Kapur RP, Studholme C, Boldenow E, Vornhagen J, Baldessari A, Dighe MK, Thiel J, Merillat S, Armistead B, Tisoncik-Go J, Green RR, Davis MA, Dewey EC, Fairgrieve MR, Gatenby JC, Richards T, Garden GA, Diamond MS, Juul SE, Grant RF, Kuller L, Shaw DW, Ogle J, Gough GM, Lee W, English C, Hevner RF, Dobyns WB, Gale M Jr, Rajagopal L (2016) Fetal brain lesions after subcutaneous inoculation of Zika virus in a pregnant nonhuman primate. Nature Medicine 22:1256-1259. doi: 10.1038/nm.4193.

Wang A, Thurmond S, Islas L, Hui K, Hai R (2017a) Zika virus genome biology and molecular pathogenesis. Emerging Microbes \& Infections 6 :e13.

Wang H, Liu S, Zhang B, Wei W (2017b) Analysis of Synonymous Codon Usage Bias of Zika Virus and Its Adaption to the Hosts. Plos One 12: $\mathrm{e} 0170128$.

Wang Q, Yang H, Liu X, Dai L, Ma T, Qi J, Wong G, Peng R, Liu S, Li J, Li S, Song J, Liu J, He J, Yuan H, Xiong Y, Liao Y, Li J, Yang J, Tong Z, Griffin BD, Bi Y, Liang M, Xu X, Qin C, Cheng G, Zhang X, Wang P, Qiu X, Kobinger G, Shi Y, Yan J, Gao GF (2016b) Molecular determinants of human neutralizing antibodies isolated from a patient infected with Zika virus. Science Translational Medicine 8: 369ra179. DOI: 10.1126/scitranslmed.aai8336.

Wang S, Hong S, Deng YQ, Ye Q, Zhao LZ, Zhang FC, Qin CF, Xu Z1(2016c) Transfer of convalescent serum to pregnant mice prevents Zika virus infection and microcephaly in offspring. Cell Research 1-3. doi: 10.1038/cr.2016.144.

Wang X, Yin F, Bi Y, Cheng G, Li J, Hou L, Li Y, Yang B, Liu W, Yang L (2016a) Rapid and sensitive detection of Zika virus by reverse transcription loop-mediated isothermal amplification. Journal of Virological Methods 238:86-93.

Way JH, Bowen ET, Platt GS (1976) Comparative studies of some African arboviruses in cell culture and in mice. Journal of General Virology 30:123-130. 
Weaver SC (2013) Urbanization and geographic expansion of zoonotic arboviral diseases: mechanisms and potential strategies for prevention. Trends in Microbiology21:360-363. doi: 10.1016/j.tim.2013.03.003

Weaver SC, Costa F, Garcia-Blanco MA, Ko AI, Ribeiro GS, Saade G, Shi PY, Vasilakis N (2016) Zika virus: History, emergence, biology, and prospects for control. Antiviral Research 130:69-80.

Wen J, Elong Ngono A, Angel Regla-Nava J, Kim K, Gorman MJ, Diamond MS, Shresta S (2017) Dengue virus-reactive CD8+ T cells mediate cross-protection against subsequent Zika virus challenge. Nature Communications 8 :1459. doi: 10.1038/s41467-017-01669-z.

Weterings R (2015) Tadpoles of three common anuran species from Thailand do not prey on mosquito larvae. Journal of Vector Ecology 40 : 230-232. doi: 10.1111/jvec. 12158 .

WHO (2016) Zika Situation Report: Zika virus, Microcephaly and Guillain-Barrê̂A syndromeĐ27 October 2016: World Health Organization; 2016 [31 October 2016]. http://www.who.int/emergencies/zika-virus/ situation-report/27-october-2016/en/.

Whyard S, Erdelyan CNG, Partridge AL, Singh AD, Beebe NW, Capina R (2015) Silencing the buzz: a new approach to population suppression of mosquitoes by feeding larvae double-stranded RNAs. Parasit Vectors 8: 96.

Williams KL, Sukupolvi-Petty S, Beltramello M, Johnson S, Sallusto F, Lanzavecchia A, Diamond MS, Harris E (2013) Therapeutic efficacy of antibodies lacking Fc receptor binding against lethal dengue virus infection is due to neutralizing potency and blocking of enhancing antibodies. PLOS Pathogens 9: e1003157. doi: 10.1371/journal.ppat.1003157.

Willison HJ, Jacobs BC, van Doorn PA (2016) Guillain-Barre syndrome. Lancet 388:717-27.

Wong SJ, Furuya A, Zou J, Xie X, Dupuis AP, Kramer LD, Shi PY (2017) A Multiplex Microsphere Immunoassay for Zika Virus Diagnosis. EBioMedicine 16:136-140.

Xu M, Lee EM, Wen Z, Cheng Y, Huang WK, Qian X, Tcw J, Kouznetsova J, Ogden SC, Hammack C, Jacob F, Nguyen HN, Itkin M, Hanna C, Shinn P, Allen C, Michael SG, Simeonov A, Huang W, Christian KM, Goate A, Brennand KJ, Huang R, Xia M, Ming GL, Zheng W, Song H, Tang H (2016b) Identification of small-molecule inhibitors of Zika virus infection and induced neural cell death via a drug repurposing screen.
Nature Medicine 22:1101-1107. doi: 10.1038/nm.4184.

Xu MY, Liu SQ, Deng CL, Zhang QY, Zhang B (2016a) Detection of Zika virus by SYBR green one-step real-time RT-PCR. Journal of Virological Methods 236:93-97.

Xu X, Vaughan K, Weiskopf D, Grifon A, Diamond MS, Sette A, Peters B (2016c) Identifying candidate targets of immune responses in Zika virus based on homology to epitopes in other flavivirus species. PLOS Currents Outbreaks

ecurrents.outbreaks.9aa2e1fb61b0f632f58a098773008c4b.Published online $2016 \quad$ November $15 . \quad$ doi: 10.1371/currents.outbreaks.9aa2e1fb61b0f632f58a098773008c4b.

Yang M, Sun H, Lai H, Hurtado J, Chen Q (2017) Plant-produced Zika virus envelope protein elicits neutralizing immune responses that correlate with protective immunity against Zika virus in mice. Plant Biotechnology Journal 2017: 1-9. doi: 10.1111/pbi.12796.

Yuan L, Huang XY, Liu ZY, Zhang F, Zhu XL, Yu JY, Ji X, Xu YP, Li G, Li C, Wang HJ, Deng YQ, Wu M, Cheng ML, Ye Q, Xie DY, Li XF, Wang X, Shi W, Hu B, Shi PY, Xu Z, Qin CF (2017) A single mutation in the prM protein of Zika virus contributes to fetal microcephaly. Science pii: eaam7120. doi: 10.1126/science.aam7120.

Zanluca C, dos Santos CND (2016) Zika viruse an overview. Microbes and Infection 18:295-301.

Zhang Q, Sun K, Chinazzi M, Pastore Y, Piontti A, Dean NE, Rojas DP, Merler S, Mistry D, Poletti P, Rossi L, Bray M, Halloran ME, Longini IM Jr, Vespignani A (2017) Spread of Zika virus in the Americas. Proceedings of the National Academy of Sciences of the United State of America pii: 201620161. doi: 10.1073/pnas.1620161114. [2017 April 25, Epub ahead of print].

Zhang S, Kostyuchenko VA, Ng TS, Lim XN, Ooi JS, Lambert S, Tan TY, Widman DG, Shi J, Baric RS, Lok SM (2016) Neutralization mechanism of a highly potent antibody against Zika virus. Nature Communications 7:13679.

Zmurko J, Marques RE, Schols D, Verbeken E, Kaptein SJ, Neyts J (2016) The viral polymerase inhibitor 7-Deaza-2'-C-Methyladenosine is a potent inhibitor of in vitro Zika virus replication and delays disease progression in a robust mouse infection model. PLOS Neglected Tropical Diseases 10:e004695. 